Eroğlu, F. ve Kalaycı, N. (2020). Üniversitelerdeki zorunlu ortak derslerden Türk dili dersinin uzaktan ve yüz yüze eğitim uygulamalarının karşılaştırılarak değerlendirilmesi. Ana Dili Eğitimi Dergisi, 8(3), 1001-1027.

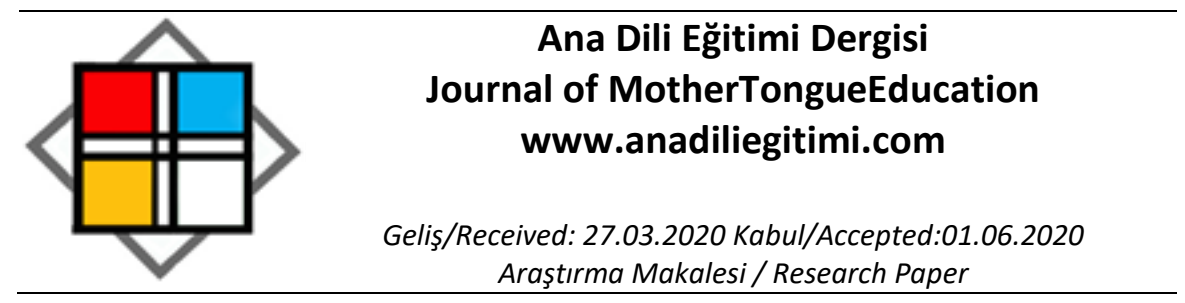

\title{
Üniversitelerdeki Zorunlu Ortak Derslerden Türk Dili Dersinin Uzaktan ve Yüz Yüze Eğitim Uygulamalarının Karşılaştırılarak Değerlendirilmesi *
}

\author{
Fahriye EROĞLU ${ }^{* *}$ \\ Nurdan $\mathrm{KALAYCl}^{* * *}$
}

Öz

Zihnimizdeki düşünceleri somut ve nesnel olarak ortaya çıkararak kendimizi ifade etmemizi, toplumda yer alan diğer insanlarla iletişim kurabilmemizi ve milli kültürümüzün oluşmasını sağlayan ana dilimiz Türkçenin öğretimi ve doğru kullanımı son derece önemlidir. Bu öneminden dolayı Türk dili dersi üniversitelerde zorunlu ortak dersler arasında yer almaktadır. Ülkemizde bazı üniversiteler ön lisans, lisans ve lisansüstü eğitim programlarında yer alan dersleri ve zorunlu ortak derslerin tümünü veya bir kısmını 2013 yılından bu yana uzaktan eğitim uygulamasıyla yürütmeye başlamıştır. Zorunlu dersler arasında yer alan Türk dili dersi de bu kapsamda uzaktan eğitim uygulaması ile yürütülmeye başlanmıştır. Üniversitelerin uzaktan eğitim uygulamasına bu yönelişinin sebebi, artan öğrenci gereksinimlerine cevap verebilmek, onlara nitelikli bir eğitim sunmak ve çağın gerektirdiği bireysel gelişimi destekleyebilmektir. Bu araştırmanın amacı, üniversitelerin eğitim programlarında yer alan zorunlu ortak derslerden Türk dili dersinin uzaktan eğitim uygulamasının öğrenci görüşlerine göre değerlendirilmesidir. Araştırmanın modeli betimsel, yöntemi ise niteldir. Araştırmanın çalışma grubu 100 öğrenciden oluşmaktadır. Bu öğrencilerden 50'si Gazi Üniversitesinde, 2016-2017 öğretim yılında, Fen Edebiyat, Mühendislik, Tıp, Eğitim ve Hukuk Fakültelerinin birinci sınıfında öğrenim gören öğrencilerdir. Diğer 50 öğrenci ise 2015- 2016 öğretim yılında, aynı fakültelerden mezun olan öğrencilerdir. Veriler, görüşme tekniği ile toplanmıştır. Veri toplama aracı ise yarı yapılandıııımış görüşme formudur. Verilerin analizinde, içerik analizi tekniği kullanılmıştır. Bulgulara göre Türk dili dersinin hem uzaktan hem de yüz yüze eğitim uygulamalarına yönelik olumsuz öğrenci görüşleri çoğunluktadır. Her iki grupta yer alan öğrenci görüşlerinin analizinden elde edilen veriler benzerdir. Öğrenciler, uzaktan ve yüz yüze eğitim uygulamasının içerik boyutunda içeriğin basit ve yetersiz olduğunu, ders işlenişi (eğitim durumu) boyutunda öğretim elemanlarının etkili öğretim yöntem ve teknikler kullanmadığını, ölçme ve değerlendirme boyutunda ise sınavların basit olduğunu belirtmiştir. Uzaktan eğitim uygulamasının üç boyutunda da yetersizliklerin olması öğrencilerin uzaktan eğitim algılarını da olumsuz yönde etkilemiştir. Bu bulguların, uzaktan eğitim uygulayan kurumlar, uygulayıcılar ve Yükseköğretim Kurulu (YÖK) tarafından dikkate alınması, öğretimin niteliğinin arttırılmasına katkı sağlayabilir.

Anahtar Kelimeler: COVID-19 pandemi, uzaktan eğitim, Türk dili, yüz yüze eğitim, zorunlu ortak dersler

\footnotetext{
* Bu makale Fahriye EROĞLU tarafından hazırlanan “Üniversitelerdeki Zorunlu Ortak Derslerin Uzaktan ve Yüz Yüze Eğitim Uygulamalarının Değerlendirilmesi" isimli yüksek lisans tezinden üretilmiştir.

** Öğretmen, MEB, Ankara,f_a_b_fb@windowslive.com, ORCID: 0000-0002-8484-2728

*** Prof. Dr., Gazi Üniversitesi, Gazi Eğitim Fakültesi, Eğitim Programları ve Öğretim Anabilim Dalı, Ankara, kalaycı@gazi.edu.tr, ORCID: 0000-0003-1982-2410
} 


\title{
Comparative Evaluation of the Distance and Face-to-face Education Practices in the Required Turkish Language Course at Universities
}

\begin{abstract}
The teaching and correct use of our mother tongue, Turkish, which enables us to express the thoughts in our minds as tangible manifestations, express ourselves, communicate with other people in the society and form our national culture is very important. Due to its significance, Turkish is taught as a core course at universities. Since 2013 some universities in Turkey have started offering all courses or only the required ones in their associate, undergraduate and graduate degree curricula in their entirety or partially through distance education. The Turkish language course, which is among the required courses, has been offered through distance education since then. The reason for universities to tend towards distance education is to be able to address the increasing student needs, offer quality education and support the contemporary need for individual development. The aim of this study is to evaluate one of the required courses in the university curricula, namely, the Turkish language course, which is offered via distance education based on student opinions. This descriptive study is qualitative by design. The sample consists of 100 students. 50 of the students were freshmen at the Gazi University in the 20162017 academic year who were attending the faculties of Science, Engineering, Medicine, Education and Law. The rest consists of students who graduated from the same faculties in the 2015-2016 academic year. The data were collected through the interview technique. The data collection tool was a semi-structured interview form. The content analysis technique was used in the analysis of the data. The findings showed that regarding both distance and face-to-face teaching of the Turkish language course, there were more negative student opinions than positive ones. The findings obtained from the analysis of the data from both groups were similar. Regarding the teaching of the Turkish language course through both distance and face-to-face education, the students stated that the course content was simple and insufficient, that the instructors were not using effective teaching methods and techniques in the teaching process, and that the exams used in assessment and evaluation were simplistic. Problems in these three areas affected students' opinions negatively regarding distance education. Taking of these findings into consideration by institutions implementing distance education, instructors and the Council of Higher Education may contribute to improving quality in the teaching of the Turkish language course.
\end{abstract}

Keywords: COVID-19 pandemic, distance education, Turkish language, face-to-face education, required courses

\section{Giriş}

Yükseköğretim sistemi, ülkelerin bilimsel, teknolojik, ekonomik, kültürel ve sosyal gelişimine katkı sağlayacak nitelikli bireyleri yetiştirmeyi amaçlamaktadır. Bu süreçte, yükseköğretim sistemi, öğrencilere nitelikli öğretim stratejilerini, yöntemlerini ve tekniklerini içinde barındıran eğitim ve öğretim programlarının geliştirilmesini sağlamalıdır. Harvey ve Green'in dönüşümsel kalite anlayışına göre eğitimin öğrencilerde değişim meydana getirmesi ve onları her açıdan güçlendirmesi gerektiği savunulmaktadır (Harvey ve Green, 1993). Üniversiteler, nitelikli bir eğitim ile öğrenci gelişimini desteklerken aynı zamanda, kendi kurumsal gelişimlerinden de sorumludur. Bu nedenlerle üniversiteler, küresel eğilim doğrultusunda yeni bir şekillenme sürecine girmiştir. Eğitimdeki yeni şekillenme; entelektüel gelişimi, öğrenmeyi, öğrenci merkezli yeni öğrenme yollarını, sosyal öğrenmeyi ve yaşam boyu öğrenmeyi kapsamaktadır (Aubusson ve Schuck, 2013).

Guberling ve Ebeling bilgi teknolojilerinin hızla çoğalması ve internet temelli öğretimi gerçekleştirmenin nispeten daha kolay olması gibi faktörlerin uzaktan eğitimin, yükseköğretimdeki önemini arttırdığını ileri sürmektedir (Guberling ve Ebeling, 1997; Akt. Karataş, 2003). Ancak uzaktan eğitimin hızla yaygınlaşması sadece teknolojik gelişmelerle sınırlı değildir. 21. yüzyılda uzaktan eğitimin yükselişine sebep olan çok sayıda teknolojik, ekonomik, politik ve sosyolojik etkenden bahsetmek mümkündür (Fırat, 2016, s. 143). Bu etkenlerin uzaktan eğitimin gelişimine ivme kazandırması eğitim uygulamalarında değişikliklere neden olmuştur (Fırat, 2016). Ayrıca, üniversitelerin öğrenci sayıları son yıllarda hızla artmaktadır. Uzaktan eğitim programları hariç öğrenci sayılarının 2014 - 2020 yılları içerisindeki dağılımı Şekil 1'de yer almaktadır. 
Üniversitelerdeki Zorunlu Ortak Derslerden Türk Dili Dersinin Uzaktan ve Yüz Yüze Eğitim Uygulamalarının Karşılaştırılarak Değerlendirilmesi

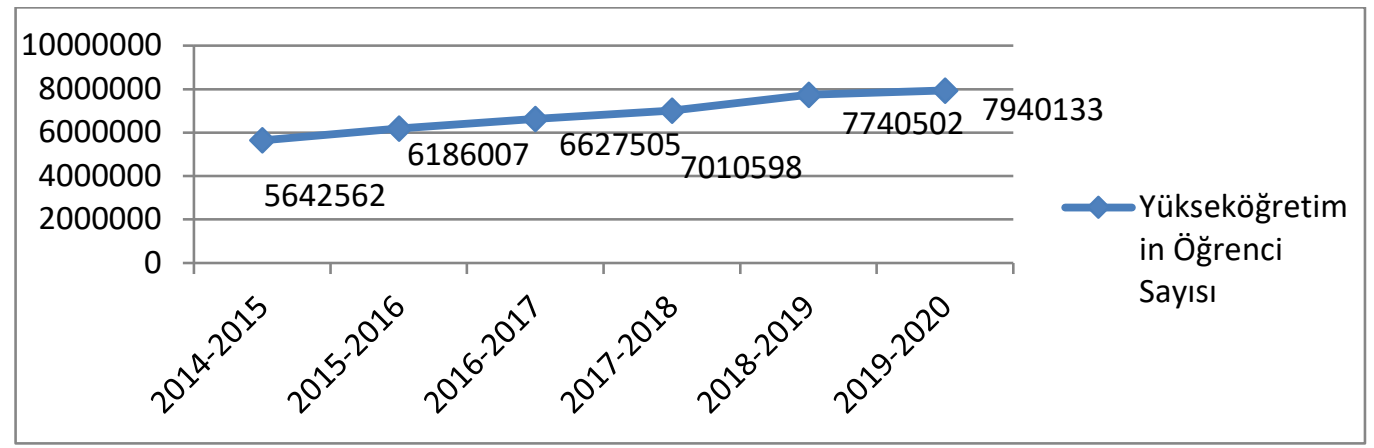

Şekil 1. Üniversitelerde öğrenim gören öğrenci sayılarının yıllara göre dağılımı. YÖK. (2020), Öğrenci sayılarının değişimi. https://istatistik.yok.gov.tr/ sayfasında yer alan verilerden yararlanarak araştırmacılar tarafından oluşturulmuştur.

Şekil 1'de görüldüğü gibi, üniversitelerde öğrenim gören öğrenci sayıları her geçen yıl artmaktadır. Bu durum bilginin öğrencilere daha kolay ve hızı olarak paylaşılması ihtiyacını ortaya çıkarmaktadır. Uzaktan eğitim sürekli gelişen ve değişen teknolojik gelişmelerin de etkisiyle günümüzdeki eğitim gereksinimlerini karşılayabilecek ve kısa sürede geniş kitlelere ulaşabilecek bir uygulamadır. Ülkemizde Mart 2020'de başlayan ve öğrencilerin yüz yüze eğitim ortamlarına devam etmesine engel olan Covid-19 pandemi süreci de uzaktan eğitim uygulamasının gerekliliğini göstermektedir. Öğrencilerin yüz yüze eğitim aldıkları okullarına devam edememesinden kaynaklı olarak eğitimde oluşan boşluk hızlı bir şekilde uzaktan eğitim uygulamasıyla doldurulmuştur.

Çok sayıda teknolojik, ekonomik, politik, sosyolojik etkenler dikkate alındığında, artan öğrenci gereksinimlerine cevap verebilmek ve onlara nitelikli bir eğitim sunabilmek için üniversiteler, uzaktan eğitim uygulamasına yönelmektedir. Bazı üniversiteler, zorunlu ortak derslerden bir ya da birkaçını uzaktan eğitim uygulaması ile yürütmeyi tercih etmişlerdir. Üniversitelerin bu tercihi, Yükseköğretim Kurulu'nu (YÖK) uzaktan eğitim ile ilgili karar alma konusunda teşvik etmiştir. Yükseköğretim Genel Kurulu'nun 01.02.2013 tarihli toplantısında alınan kararlara göre; Yükseköğretim kurumlarının; ön lisans, lisans ve yüksek lisans düzeyinde diploma programları ile senatoları tarafından uygun görülmesi halinde, birinci ve ikinci öğretim programlarındaki bazı dersleri uzaktan eğitim yoluyla verilebilir." "Uzaktan eğitim programları ile uzaktan eğitim yoluyla verilmesi uygun görülen dersler, ağ üzerinden eşzamanlı olarak çevrimiçi teknolojilerle verilir. Derslerin yürütülmesinde kitap, radyo, televizyon, ses ve görüntü diskleri (CD/DVD) vb. çevrimdışı teknolojilerden de yararlanılabilir. Öğretim, yüz yüze ders ve uygulamalarla da desteklenebilir" (YÖK, 2013).

Yapılan bu düzenlemeyle birlikte zorunlu ortak dersleri (Atatürk İlkeleri ve İnkılap Tarihi, Türk dili ve yabancı dil) uzaktan eğitim uygulamasıyla yürüten üniversitelerin sayısı artmıştır. Şu an üniversitelerin yaklaşık \%67'sinde (176 üniversitenin 117'sinde) zorunlu ortak dersler uzaktan eğitim uygulamasıyla yürütülmektedir.

Gazi Üniversitesi'nin de arasında bulunduğu 117 üniversitenin, 2013-2017 yılları arasında zorunlu ortak derslerin verilişinin uzaktan eğitim uygulamasına geçmiş olması kayda değer bir durum olarak değerlendirilmektedir. Üniversitelerin \%67'sinin hızlı bir şekilde uzaktan eğitim uygulamasına başlaması, yapılan uygulamaların çeşitli boyutlarda incelenip değerlendirilmesi gereksinimini ortaya çıkarmıştır.

Bu araştırmada zorunlu ortak derslerden, Türk dili dersinin uzaktan eğitim uygulamasının değerlendirilmesi amaçlandığından iki kavramı ayrıntılı olarak açıklamak uygun olacaktır.

\section{Zorunlu Ortak Dersler}

Tüm öğrencilerin eğitimsel deneyimlerini ve bilgilerini birleştiren tutarlı bir eğitim programı, kapsamlı bir öğrenme sağlamaktadır. Üniversiteler, öğrencilere disiplinler arası bir eğitim programı uygulamayı hedeflemelidir. Bu nedenle üniversiteye başlayan öğrencilere, Atatürk illkeleri ve İnkılap Tarihi, Türk dili ve yabancı dil dersleri zorunlu ortak dersler kapsamında verilmektedir. Bu dersler, 
Yükseköğretim Kanunun 5. Maddesinin ı bendinde yer aldığı için "5ı Dersleri" olarak da isimlendirilir. YÖK'ün ilgili kararı aşağıda yer almaktadır.

Madde 5 - Yükseköğretim, aşağıdaki "Ana Illkeler" doğrultusunda planlanır, programlanır ve düzenlenir:

I) Yükseköğretim kurumlarında, Atatürk Illkeleri ve İnkılâp Tarihi, Türk dili, yabancı dil zorunlu derslerdendir. Ayrıca, zorunlu olmamak koşuluyla beden eğitimi veya güzel sanat dallarındaki derslerden birisi okutulur. Bütün bu dersler en az iki yarıyıl olarak programlanır ve uygulanır (Yükseköğretim Kanunu, 1981).

Zorunlu ortak dersler eğitim fakültelerinde genel kültür dersleri kapsamında verilmektedir. Belirlenen bu dersler bazı üniversitelerde değişiklik göstermesine rağmen genel olarak, üniversitelerin birinci sınıfında, iki yarıyıl süresince, haftada iki veya üç ders saati olarak okutulmaktadır. Bu durum Tablo 1'de özetlenmektedir.

Tablo 1.

Öğrencilerin Üniversite 1. Sınıfta Aldıkları Zorunlu Ortak Derslerin ve Bu Derslerin Kredilerinin Dağııımı

\begin{tabular}{lcc}
\hline & $\begin{array}{l}\text { 1. Dönem } \\
\text { ( Lab+ Uyg+ Teo(saat)) }\end{array}$ & $\begin{array}{l}\text { 2. dönem } \\
\text { ( Lab+ Uyg+ Teo(saat)) }\end{array}$ \\
\hline Yabancı Dil & $0+0+3$ & $0+0+3$ \\
\hline Türk Dili & $0+0+2$ & $0+0+2$ \\
\hline Atatürk Illkeleri ve İnkılapları Tarihi & $0+0+2$ & $0+0+2$ \\
\hline
\end{tabular}

Gazi Üniversitesi. (2018). http://guzem.gazi.edu.tr/posts/view/title/yok-5\%28i\%29-ortak-dersleri115157 ?siteUri=guzem sayfasından erişilmiştir.

\section{Türk Dili Dersinin Önemi ve Tarihi Gelişimi}

Dil, uzlaşımsal olduğu için öğretilmelidir. Çünkü dil, en yetkin ileti kodudur. İnsanlar arasında kullanılan en gelişmiş iletişim aracıdır. Dil aracılığıyla iç ve dış dünyamızdaki somut ve soyut kavramları ifade edebilmekteyiz. Dil, insanın kendisini ifade etme aracıdır. Toplumsal uyumun temelidir (Onan, 2012).

Kişinin ana dilini öğrenmesi ve etkili bir şekilde kullanması kişiliğinin, duygusal ve zihinsel gelişiminin en önemli tamamlayıcısıdır. Ayrıca ana dili düşünce üretmemizi ve tartışma etkinliklerine katılmamızı sağlamaktadır. Bu nedenle üniversitelerde ana dili öğretimi, öğrencilerin dili kullanma becerisi, dil bilinci, dil duyarlılığı ve yaratıcılığını ortaya çıkarmalıdır (Önkaş, 2010). Ancak ana dili öğretimine ilköğretimden yükseköğretime kadar eğitimin her kademesinde yer verilmesine rağmen Türk dili çerçeve programda yer alan hedeflere ulaşılamamaktadır (Demir ve Yapıcı, 2007; Tezcan, 1983; Yangın, 2001). Ana dilinin doğru ve etkili, bir biçimde kullanılması ancak işlevsel bir dil öğretimi ile mümkün olacaktır (Önkaş, 2010). Eğitim uygulamalarındaki yeni yaklaşımlar ve değişiklikler ile yeni öğretme- öğrenme modellerinin kullanımı ana dilin öğretiminde, okuduğunu anlama ve yazılı anlatım becerilerinin kazandırılmasında etkilidir (Sever, 2002).

Illk olarak Ankara Üniversitesi, Dil ve Tarih-Coğrafya Fakültesi'nin lisans programında yer alan Türk dili dersi, YÖK'ün 1981 yılında kurulmasıyla birlikte üniversitelerin önlisans/lisans programlarının tamamında zorunlu dersler arasında yer almıştır (Karataş, 2013). Bu ders, birinci dönem Türk dili 1 (101), ikinci dönem ise Türk dili 2 (102) dersi olarak bütün fakülte ve yüksekokulların birinci sınıfında iki AKTS kredili olarak yer alan zorunlu ortak derstir. Türk dili 1 ve Türk dili 2 dersinin temel amacı, öğrencilerin, temel dil becerilerinden olan anlama ve anlatma becerilerini (dinleme, okuma, konuşma, yazma) geliştirmek; okuduklarını, dinlediklerini, eleştirel bir bakış açısıyla çözümlemelerine olanak tanımak; anladıklarını, duygu ve düşüncelerini doğru, anlaşılır bir Türkçe ile yazılı ya da sözlü ifade etmelerini sağlamaktır (Akkaya ve Sevindi, 2015). Göğüş (1983)'e göre, ana dil eğitiminden beklenen; anlam ve duyguya göre vurgulayarak düzgün ve doğru bir okuma; iyi dinleme; okuduğunu, dinlediğini doğru ve tam anlama; doğru konuşup doğru yazma; yeterli bir söz dağarcığı kazanma; dil kurallarını öğrenip uygulamaya çalışma yeteneği kazandırmaktır. 
Türk dili dersinin çerçeve programda zorunlu ders olarak yer alma sebebi; "ilk ve orta öğretimde dil bilgisi ve Türkçe dersleri yeterli ölçü ve nitelikte ele alınmadığı için üniversiteye gelen öğrenciler, dillerini doğru ve güzel kullanma yeteneği kazanamamıştır. Bu durum, üniversite öğrencisi için yetersizlik olarak kendini göstermiş ve yükseköğretim programlarına Türk dili derslerinin eklenmesini zaruri kılmıştır (Vural, 2007) şeklinde açıklanmıştır. Türk dili dersinin, YÖK tarafından belirlenen çerçeve programa göre hedefleri şunlardır;

1. Türkçenin yapı ve işleyiş özelliklerini kavrama,

2. Dili yazılı ve sözlü anlatımda kullanma yeteneği kavrama,

3. Ana dil şuuruna sahip gençler yetiştirme,

4. Çalışmaları özellikle retorik alanında yoğunlaştırma (Cemiloğlu, 2004).

YÖK tarafından belirlenen çerçeve program ve Türk dili dersinin amaçları doğrultusunda Gazi Üniversitesinde, tüm lisans/önlisans eğitim programlarının birinci sınıfında iki dönem boyunca okutulmaktadır.

Zorunlu ortak dersler, 1981 yılında yüz yüze eğitim ile başlamış, ancak bu derslerin ilk verildiği dönemden günümüze eğitim sistemimiz birçok değişikliğe uğramıştır. Zorunlu ortak dersler de bu değişimlerden etkilenmiştir. 2013-2014 öğretim yılında YÖK'ün aldığı kararla Gazi Üniversitesi'nde zorunlu ortak dersler uzaktan eğitim uygulaması ile yapılmaya başlamıştır.

Yükseköğretim Kanunu'nun 5(ı) maddesi kapsamında yer alan "Yabancı Dil (İngilizce) 1 ve 2", "Türk Dili 1 ve 2" , "Atatürk İlkeleri ve İnkılap Tarihi 1 ve 2" dersler Gazi Üniversitesi Uzaktan Eğitim Uygulama ve Araştırma Merkezi (GUZEM) tarafından uzaktan eğitim yoluyla yürütülmektedir. GUZEM, ders materyallerinin hazırlanması, bu materyallerin dijital ortamda depolanması ve öğrencilerin materyallere erişimini sağlamaktadır. GUZEM tarafından PDF formatındaki ders notları ve haftalık ders videoları öğretim yönetim sistemine eklenerek internet üzerinden öğrencilere sunulmaktadır. Dersler eş zamansız (çevrimdışı/ asenkron) olarak verilmektedir. Gazi üniversitesinde yapılan zorunlu ortak derslerin uzaktan eğitim uygulamasının işlem basamakları Tablo 2'de özetlenmiştir.

Tablo 2.

Gazi Üniversitesinde Yapılan Zorunlu Ortak Derslerin Uzaktan Eğitim Uygulamasının Yapısı

- Yeni kayıt yaptıran öğrenciler, ders kayıt döneminde Derslere Kayıt Olma https://ogrenci.gazi.edu.tr/ adresinden bu derslere kayıt yaptırmaları gereklidir.

- uzem.gazi.edu.tr adresinden derslere erişim sağlanır.

- Bilgisayar, tablet ve cep telefonu ile giriş yapılabilir.

Öğrenci Yönetim

Sistemine Giriş Yapma

- Gerekli bilgiler;

Kullanıcı Adı: Gazi öğrenci numarasıdır.

Şifre: T.C. numarasının soldan ilk 6 hanesidir.

- Ders ekle/bırak süreci tamamlandıktan iki hafta sonra ders videoları erişime açılır.

Ders İçerikleri

- Videolar çevrimdışı ortamda sunulmaktadır.

- Öğrencilere haftalık olarak PDF formatında ders materyali sunulmaktadır.

- Vize, final ve bütünleme GAZISEM tarafından merkezi olarak yapılmaktadır ve değerlendirilmektedir.

Derslerin

Değerlendirilmesi

- Sınav tarihleri ve sınava dahil olan konular Öğrenci İşleri Bilgi Sistemi internet sayfasından duyurulmaktadır.

- Öğrenciler, sınav giriş belgelerini GAZISEM adresi üzerinden sınav öncesi almalıdır.

- Öğrenciler öğretim elemanlarına soru sorabilmeleri için dersi Iletişim veren öğretim elemanının dersle ilgili tartışma formu oluşturması gereklidir. 
Zorunlu ortak derslerde yer alan hedeflerin öğrencilere kazandırılması, Gazi Üniversitesi gibi çoğu üniversitede uzaktan eğitim uygulaması ile yapılmaya başlamıştır. Tasarlanan uzaktan eğitim uygulamasında, sürecin niteliğini belirleyebilmek, süreç boyunca yaşanan sorunlarla ilgili gözlemler yapabilmek uygulamanın geliştirilebilmesi ve iyileştirmelerin zamanında yapılabilmesi için çok önemlidir. Bu durum araştırmanın konusu olan Türk dili dersinin uzaktan eğitim uygulamasının çeşitli boyutlarda incelenip değerlendirilmesine dair bilimsel araştırmaların yapılması gereksinimini doğurmuştur. Zorunlu ortak derslerden Türk dili dersinin uzaktan eğitim uygulamasına ilişkin üniversite öğrencilerinin görüşlerinin belirlenmesi amacıyla yapılan araştırmalar (Kan ve Fidan, 2016; Korkmaz, Kalkan, Doğan, Doğruluk, Aydın; 2018) oldukça sınırlıdır. Araştırma sonuçlarında genel olarak derse katılım oranının azlığı, teknik problemler, sınavlarda yaşanılan problemler, derslerin ilgi çekici ve verimli olmaması (Kan ve Fidan, 2016; Korkmaz vd.; 2018) gibi çeşitli sorunlar yaşandığı sonucuna ulaşılıştır. Araştırmaların yapılarak Türk dili dersinin uzaktan ve yüz yüze eğitim uygulamaların karşılaştıılarak değerlendirilmesi gereklidir. Ayrıca yapılan araştırmaların sonucuna göre uygulamalarda varsa problemlerin giderilmesi, yaşanacak olası durumlara karşı önlem alınabilmesi ve bir problemle karşılaşıldığında farklı çözümler üretilebilmesi önemlidir.

Bu araştırmada üniversitelerin eğitim programlarında yer alan zorunlu ortak derslerden Türk dili dersinin uzaktan ve yüz yüze eğitim uygulamalarının karşılaştırılarak değerlendirilmesi amaçlanmıştır.

Bu temel amaca ulaşmak için belirlenen alt amaçlar:

1. Zorunlu ortak derslerden Türk dili dersinin yüz yüze ve uzaktan eğitim uygulanmalarına yönelik öğrenci görüşlerinin karşılaştırılarak değerlendirilmesi,

2. Zorunlu ortak derslerin uzaktan ve yüz yüze eğitim uygulamalarının avantaj ve dezavantajlarının saptanmasıdır.

\section{Araştırmanın Modeli}

\section{Yöntem}

Araştırmanın modeli betimseldir ve araştırmada nitel araştırma yöntemi kullanılmıştır. Araştırmada zorunlu ortak derslerin uzaktan ve yüz yüze eğitim uygulamaları tam ve dikkatli bir şekilde analiz edilmiştir (Büyüköztürk, Çakmak, Akgün, Karadeniz ve Demirel, 2013). Nitel araştırma, incelenen problemin doğal ortamındaki biçimini anlamaya yönelik olarak problemi sorgulayıcı ve yorumlayıcı bir yöntemdir (Guba ve Lincoln, 1994; Klenke, 2016). Bu özellikleriyle araştırma bir durum çalışmasıdır.

\section{Araştırma grubu}

Araştırmanın iki çalışma grubu bulunmaktadır. Birinci çalışma grubu 2016-2017 öğrenim yılında Gazi Üniversitesinin fen edebiyat, mühendislik, tıp, eğitim ve hukuk fakültelerinde birinci sınıfta öğrenim gören toplam 50 öğrenciden; ikinci çalışma grubu ise 2015- 2016 öğrenim yılında aynı üniversitenin aynı fakültelerinden mezun olan toplam 50 öğrenciden oluşmuştur. Birinci çalışma grubundaki öğrenciler zorunlu ortak dersleri uzaktan eğitim ile ikinci çalışma grubundaki öğrenciler ise bu dersleri yüz yüze eğitim uygulaması ile almışlardır. Mezun öğrencilerin seçilme nedeni zorunlu ortak dersleri yüz yüze eğitim uygulamasıyla alan son öğrenci grubu olmalarıdır.

Araştırmanın çalışma grubunun oluşturulmasında, amaçsal örnekleme yönteminin bir alt boyutu olan, 'maksimum çeşitlilik' örnekleme yöntemi kullanılmıştır. Maksimum çeşitlilik yönteminde, çeşitlilik gösteren durumlar arasından herhangi bir ortak olguyu bulmaya çalışmak ve bu çeşitliliğe göre problemin farklı boyutlarını incelemek hedeflenir (Marczyk, DeMatteo, Festinger, 2005). Bu örneklem yöntemi doğrultusunda çalışma grubunu oluşturan Gazi Üniversitesindeki öğrenci sayılarının fakültelere ve sınıf düzeylerine göre dağııımı Tablo 3'te yer almaktadır. 
Üniversitelerdeki Zorunlu Ortak Derslerden Türk Dili Dersinin Uzaktan ve Yüz Yüze Eğitim Uygulamalarının Karşılaştırılarak Değerlendirilmesi

Tablo 3.

Araştırmanın Çalışma Grubu

\begin{tabular}{|c|c|c|}
\hline FAKÜLTELER & SINIF DÜZEYI & ÖĞRENCI SAYISI \\
\hline \multirow{2}{*}{ Eğitim } & 1. Sinif & 10 \\
\hline & Mezun & 10 \\
\hline \multirow{2}{*}{ Hukuk } & 1. Sinıf & 10 \\
\hline & Mezun & 10 \\
\hline \multirow{2}{*}{ Fen Edebiyat } & 1. Sinıf & 10 \\
\hline & Mezun & 10 \\
\hline \multirow{2}{*}{ Mühendislik } & 1. Sinıf & 10 \\
\hline & Mezun & 10 \\
\hline \multirow{2}{*}{ Tıp } & 1. Sinıf & 10 \\
\hline & Mezun & 10 \\
\hline Toplam & & 100 \\
\hline
\end{tabular}

\section{Veri Toplama Araçları}

Bu araştırmada "Uzaktan Eğitim Görüşme Formu" ve "Yüz Yüze Eğitim Görüşme Formu" olarak adlandırılan iki veri toplama aracı kullanılmıştır. Görüşme formları yarı yapılandırılmıştır. Formların her biri iki bölümden oluşmaktadır. Birinci bölüm kişisel bilgileri, ikinci bölüm ise uzaktan ve yüz yüze eğitim uygulamalarıyla ilgili 11 açık uçlu soruyu içermektedir.

\section{Verilerin Toplanması}

2016-2017 öğretim yılında, araştırmanın çalışma grubunu oluşturan öğrencilerin tümüyle yüz yüze görüşmeler yapılmıştır. Birinci sınıf öğrencileri ile bahar döneminin sonunda yapılan görüşmeler, öğrencilerin üniversitede bulundukları zaman aralığında araştırmacılar tarafından yapılmıştır. Mezun olan öğrencilerle görüşme yapabilmek için ise belirlenen fakültelerin öğrenci işleri daire başkanlığından öğrencilerin iletişim bilgilerine ulaşılmıştır. Araştırmacılar, mezun öğrenciler ile iletişime geçerek Ankara'da bulunan ve görüşmeyi kabul eden öğrencilerle görüşmeler yapmıştır. Öğrenciler görüşme sürecinde ses kayıt cihazı kullanılmasına izin vermemişlerdir. Bu nedenle soruların cevapları görüşme formları üzerine not edilmiştir.

\section{Verilerin Analizi}

Görüşme formlarından elde edilen verilerin analizinde içerik analizi tekniği kullanılmıştır. İçerik analizinde temelde yapılan işlem, birbirine benzeyen verileri belirli kavramlar ve temalar çerçevesinde bir araya getirmek ve bunları okuyucunun anlayabileceği bir biçimde düzenleyerek yorumlamaktır (Yıldırım ve Şimşek, 2013, s. 259). Bu temel amaç çerçevesinde nitel verilerin analizi ilk olarak öğrenci görüşme formları fakültelere ve sınıf düzeylerine göre gruplara ayrılarak klasörler oluşturulmuştur. Katılımcıların görüşme formlarında yer alan sorulara verdikleri cevaplar her bir sorunun altına kod isimleriyle (E1, E4.1, H1, H4.3, M1, M4.2, F1, F4.8, T1, T4.2 vb.) birlikte öğrencilerin orijinal fikirleri yazılarak metin dosyaları oluşturulmuş ve bu dosyalar bilgisayar ortamında ilgili klasörlere eklenmiştir. Böylece 100 adet görüşme formu bilgisayar ortamına aktarılmıştır. Her bir öğrencinin bir soruya verdiği orijinal fikirlerden kodlar, bu kodlardan içeriği benzer olanlardan alt temalar, içeriği benzer alt temalar gruplandırılarak temalar oluşturulmuştur. Görüşme formlarında yer alan her bir soruya ilişkin kodların, alt temaların ve temaların gösterildiği tablolar düzenlenmiştir. Daha sonra araştırmanın amacı gereği uzaktan ve yüz yüze eğitim alan öğrencilerden toplanan verilerin karşılaştırılabilmesi için benzer olan soruların yer aldığı tablolar birleştirilmiştir. Son aşamada ise toplanan verilere anlam kazandırmak için bulgulardan birtakım sonuçlar çıkarılmış ve bulgular alan yazında bulunan benzer, tamamlayıcı ve farklılaşan araştırmalarla desteklenmiştir. 


\section{Geçerlik ve Güvenirlik}

Görüşme formlarının kapsam geçerliliğine ilişkin olarak ikisi ölçme değerlendirme diğer ikisi eğitim programları ve öğretim ana bilim dalı alan uzmanları olmak üzere dört alan uzmanından görüş alınmış ve pilot uygulama yapılmıştır. Görüşme formlarının pilot uygulaması zorunlu ortak dersleri uzaktan ve yüz yüze alan iki gruba yapılmıştır. Pilot uygulamaya 20 öğrenci katılmıştır. Alan uzmanlarından alınan görüşler ve pilot uygulamadan elde edilen veriler doğrultusunda soruların sıralaması araştırmanın amacına uygun olarak yeniden düzenlenmiştir. Ayrıca, uzaktan eğitim görüşme formunda yer alan birinci sorudaki anlatım bozukluğu düzeltilmiştir.

Araştırmanın yöntemi, ilgili kavramlar ve Gazi Üniversitesinde uygulanan uzaktan eğitim uygulaması okuyucuların kendi çalışmalarına uygunluğuna/transfer edilebilirliğine karar verebilecekleri şekilde ayrıntılı olarak açıklanmıştır. Bu araştırmanın dış geçerliliğini (transfer edilebilirlik) artırmak için yapılmıştır (Miles, Huberman ve Saldana, 2013).

Bu araştırmanın iç güvenirliğini sağlamak amacıyla araştırmadan elde edilen veriler ve analiz sonuçlarında ortaya çıkarılan kod ve temalar başka araştırmacıların incelemesine olanak verecek şekilde kayıt altında alınmıştır (Walker, 2012).

Araştırmanın dış güvenirliğini (aktarılabilirliği) artırmak amacıyla araştırma sonuçlarının, öznel varsayımlardan ve önyargılardan etkilenme olasılığını azaltmak için verilerin birbiriyle olan ilişkileri, bir bütün olarak sergilediği örüntüler ve verilerin analiz aşamaları ayrıntılı biçimde açıklanmıştır (Miles vd., 2013).

\section{Bulgular}

Araştırmanın amacı doğrultusunda alt amaçlara ait karşılaştırmalı tablolar yapılmış ve bu tablolar olabildiğince ayrıntılı şekilde yorumlanmıştır.

\section{Türk Dili Dersinin Yüz Yüze ve Uzaktan Eğitim Uygulanmalarına Yönelik Öğrenci Görüşlerinin Karşılaştırılarak Değerlendirilmesi}

Türk dili dersinin yüz yüze ve uzaktan eğitim uygulamasına yönelik öğrenci görüşleri, eğitim programının içerik, eğitim durumu (ders işlenişi), ölçme ve değerlendirme boyutlarında analiz edilmiştir. Her iki eğitim uygulamasında da dersin hedefleri ortak olduğundan ve bu hedefler YÖK tarafından belirlendiğinden bu boyut araştırmaya dahil edilmemiştir.

\section{Dersin içeriği:}

Zorunlu ortak dersleri yüz yüze ve uzaktan eğitim uygulaması ile alan öğrencilerin Türk dili dersinin içeriği ile ilgili görüşleri Tablo 4'te yer almaktadır. 
Tablo 4.

Zorunlu Ortak Dersleri Uzaktan ve Yüz Yüze Eğitim Uygulaması Yoluyla Alan Öğrencilerin, Türk Dili Dersinin Içeriği Ile Ilgili Görüşlerinin Karşılaştırılması

\begin{tabular}{|c|c|c|c|c|c|c|c|c|c|c|c|}
\hline \multicolumn{6}{|c|}{ Uzaktan Eğitim Alan Öğrencilerin Türk Dili Dersinin Içeriği ile Ilgili Görüşleri } & \multicolumn{6}{|c|}{ Yüz Yüze Eğitim Alan Öğrencilerin Türk Dili Dersinin Içeriği ile Ilgili Görüşleri } \\
\hline 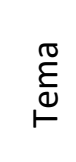 & 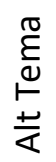 & $\begin{array}{l}\text { 음 } \\
\text { a }\end{array}$ & 4 & $\stackrel{\frac{\varepsilon}{\pi}}{\frac{\pi}{2}} \frac{0}{\circ}$ & $\frac{\frac{\varepsilon}{\pi}}{\frac{0}{0}}$ & 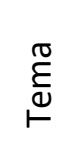 & 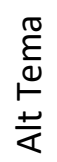 & $\begin{array}{l}\text { 무 } \\
\text { ㅁ }\end{array}$ & 4 & $\frac{\frac{E}{2}}{\frac{\pi}{2}}$ & $\frac{\frac{\varepsilon}{\pi}}{\frac{\pi}{0}}$ \\
\hline \multirow{13}{*}{ 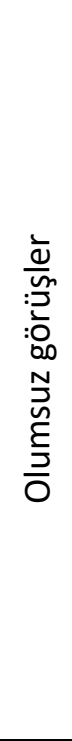 } & \multirow{7}{*}{ 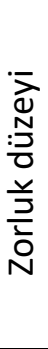 } & Konuların kolay olması & 3 & & & \multirow{13}{*}{ 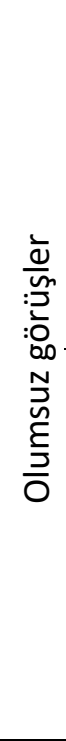 } & \multirow{7}{*}{ 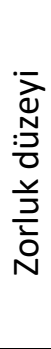 } & \multirow{3}{*}{$\begin{array}{l}\text { Eğitim hayatımız boyunca sık sık görülen ve } \\
\text { işlenen konuları içermesi }\end{array}$} & \multirow{3}{*}{5} & & \\
\hline & & Konuların lise düzeyinde olması & 2 & & & & & & & & \\
\hline & & Çok derin konular olmaması & 1 & & & & & & & & \\
\hline & & Hatırlanan bilgiler olması & 1 & & & & & Konuların lise düzeyinde olması & 3 & & \\
\hline & & Seviyenin çok düşük olması & 1 & & & & & & & & \\
\hline & & Orta zorlukta olması & 1 & & & & & \multirow{2}{*}{$\begin{array}{l}\text { Derslerde bir yıl boyunca empati üzerine } \\
\text { konuşulması }\end{array}$} & \multirow{2}{*}{1} & & \\
\hline & & Bilinmesi gereken konuları içermesi & 1 & 10 & & & & & & 9 & \\
\hline & \multirow{6}{*}{ 竞 } & Bilgilerin ayrıntılı olması & 4 & & & & \multirow{6}{*}{ 产 } & Çok gereksiz bilgileri içermesi & 2 & & \\
\hline & & Gereksiz içeriğe sahip olması & 3 & & & & & Yeterli olmaması & 2 & & \\
\hline & & \multirow[t]{2}{*}{ Öğretilen bilginin olmaması } & 2 & & & & & \multirow{2}{*}{$\begin{array}{l}\text { Öğrencilerin gelece } \\
\text { bir ders olmaması } \\
\text { Verimsiz olması }\end{array}$} & 1 & & \\
\hline & & & & & & & & & 1 & & \\
\hline & & \multirow[t]{2}{*}{ Gereksiz dil anlatım konularını içermesi } & 1 & & & & & \multirow{2}{*}{$\begin{array}{l}\text { Öğretim görevlisinin dersi anlatmak yerine } \\
\text { siyaset yapması }\end{array}$} & 1 & & \\
\hline & & & & 10 & 20 & & & & & 7 & 16 \\
\hline \multirow{5}{*}{ 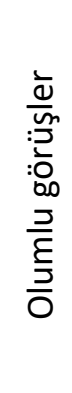 } & 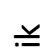 & Güzel bir içeriğe sahip olması & 3 & & & \multirow{5}{*}{ 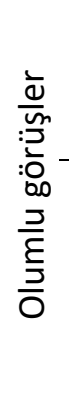 } & 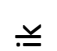 & \multirow[b]{2}{*}{ İçeriğin yeterli olması } & \multirow[b]{2}{*}{5} & & \\
\hline & 竝 & Ders içeriğinin tam olarak yeterli olması & 3 & 6 & & & 㐫 & & & 5 & \\
\hline & \multirow{3}{*}{ : } & Basit ve anlaşılır olması & 2 & & & & \multirow{3}{*}{ 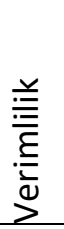 } & \multirow{3}{*}{$\begin{array}{l}\text { Derslerde öğretilen yeni kavramlar açısından } \\
\text { derslerin verimli olması }\end{array}$} & \multirow{3}{*}{2} & & \\
\hline & & Verimli olması & 1 & & & & & & & & \\
\hline & & Tanımların öğrenim için etkili olması & 1 & 4 & 10 & & & & & 2 & 7 \\
\hline
\end{tabular}




\begin{tabular}{|c|c|c|c|c|c|c|c|c|c|}
\hline \multirow{4}{*}{ 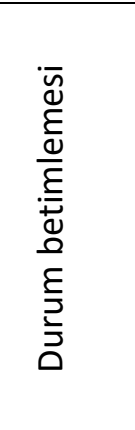 } & Dil bilgisi ve kavramları içermesi & 2 & & & \multirow{4}{*}{ 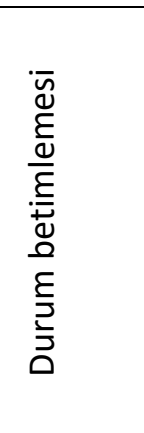 } & $\begin{array}{l}\text { Dil kullanımı, doğru konuşma ve yazma hakkında } \\
\text { dersler yapılması }\end{array}$ & 3 & \multirow[b]{4}{*}{5} & \multirow[b]{4}{*}{5} \\
\hline & Dil bilgisi ve anlatım bozukluğunu içermesi & 2 & & & & Dil bilgisi konusu üzerinde çok durulması & 1 & & \\
\hline & Daha çok örneklere yer verilmiş olması & 1 & & & & & & & \\
\hline & $\begin{array}{l}\text { Ses ve biçim özellikleri, halk edebiyatı, divan } \\
\text { edebiyatı, Tanzimat edebiyatı, edebi eserler vb. } \\
\text { konuları içermesi }\end{array}$ & 1 & 6 & 6 & & $\begin{array}{l}\text { Türkçeyi düzgün kullanma, dilekçe, mektup } \\
\text { yazma, topluluk önünde konuşma becerilerinin } \\
\text { geliştirilmesi konularını içermesi }\end{array}$ & 1 & & \\
\hline \multirow{3}{*}{ 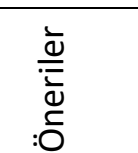 } & Dilbilgisi konusu daha ayrıntılı olmalı & 1 & & & \multirow{3}{*}{$\frac{\frac{\grave{d}}{\overline{\frac{1}{U}}}}{: 0}$} & İçeriğinde diksiyon ve telaffuzda olmalı & 3 & & \\
\hline & Bireylerin dilini düzgün yazıp okuması için bu & & & & & İçerik daha nitelikli olmalı & 1 & & \\
\hline & konuların kavranması sağlanmalı & 1 & 2 & 2 & & Öğrencilerin seviyesine uygun olmalı & 1 & 5 & 5 \\
\hline Toplam & & 38 & 38 & 38 & Toplam & & 33 & 33 & 33 \\
\hline
\end{tabular}


Tablo 4 incelendiğinde olumsuz görüşlerin frekansı her iki grupta da olumlu görüşlerden yaklaşık iki kat daha yüksektir. İki gruptaki öğrencilerin de olumsuz görüşlerinin nedenleri ortaktır ve bu görüşler Türk dili ders içeriğinin zorluk düzeyi ile ilgilidir. Öğrenciler Türk dili ders içeriğinin üniversite öncesindeki eğitim kademelerinde öğrendikleri basit konulardan oluştuğunu belirtmektedir. Cemiloğlu'na göre (2004), öğrencinin bir yıl önce karşılaştı̆̆ı konuların yine aynı yöntemle tekrar verilmesi öğrencide kesin olarak bıkkınlık hissi yaratacaktır. Onun yerine aynı amaca hizmet eden fakat en azından işleyiş tarzını değiştiren bir başka yolun denenmesi uygun olacaktır. Ayrıca öğrenciler, derslerin verimsiz olduğunu ve dersin içeriğinin gereksiz ayrıntılar içerdiğini düşünmektedir. Karataş (2013) tarafından yapılan araştırmada da, Türkçe ile ilgili en önemli sorunun öğrencilerin, ana dillerine yönelik olumsuz tutum sahibi olmaları olduğu belirtilmiş ve bunun en önemli nedeninin üniversite öncesindeki yetersiz Türkçe eğitimi olduğu, üniversitede okutulan Türk dili dersinin de bu tutumun ortadan kalkmasında çok önemli olduğu belirtilmiştir. Bu bulguyla araştırmanın bulguları benzerlik göstermektedir.

Uzaktan eğitim alan öğrenciler, bu dersin içeriğinin yeterli, basit ve anlaşılır olduğunu ifade etmişlerdir. Ayrıca her iki grupta yer alan öğrenciler ders içeriğini verimli bulmaktadır. Yüz yüze eğitim alan öğrencilerden bazıları derslerin verimli olmasına ilişkin olarak, ders süresince yeni kavramlar öğrenmelerini neden olarak göstermişlerdir.

Uzaktan ve yüz yüze eğitim alan öğrenciler içeriğin genel olarak dil bilgisi konuları üzerine yoğunlaştığını, ayrıca mektup, dilekçe yazma ve konuşma becerilerinin de içerikte yer aldığını belirtmişlerdir.

Türk dili dersinin içeriğiyle ilgili öğrenciler, konuların daha ayrıntılı olması gerektiğini ve kalıcı öğrenmenin sağlanması gerektiğini söylemişlerdir. Bilgilerin kalııı ve hatırlanabilir olması için ders hedeflerinin tasnif edilerek belirli başlıklar altında ayrıntılı bir şekilde yapılandırılması gerekmektedir (Onan, 2017). Yüz yüze eğitim alan öğrenciler ise Türk dili dersinin içeriğinde konuşma becerilerinin de yer alması gerektiğini ayrıca öğrenciler, konuların üniversite öğrencilerinin seviyesine uygun olarak tekrar düzenlenmesi gerektiğini belirtmişlerdir.

\section{Dersin işlenişi (eğitim durumu);}

Zorunlu ortak dersleri yüz yüze ve uzaktan eğitim uygulaması ile alan öğrencilerin Türk dili dersinin ders işlenişi (eğitim durumu) ile ilgili görüşleri Tablo 5’ te yer almaktadır. 
Tablo 5.

Zorunlu Ortak Dersleri Uzaktan ve Yüz Yüze Eğitim Uygulaması Yoluyla Alan Öğrencilerin, Türk Dili Dersinin Işslenişi (Eğitim Durumu) ile ilgili Görüşlerinin Karşılaştırılması

\begin{tabular}{|c|c|c|c|c|c|c|c|c|c|c|c|}
\hline \multicolumn{6}{|c|}{$\begin{array}{l}\text { Uzaktan Eğitim Alan Öğrencilerin Türk Dili Dersini işlenişi (Eğitim Durumları) } \\
\text { ile Illgili Görüşleri }\end{array}$} & \multicolumn{6}{|c|}{$\begin{array}{l}\text { Yüz Yüze Eğitim Alan Öğrencilerin Türk Dili Dersinin İşlenişi (Eğitim Durumu) } \\
\text { ile İlgili Görüşleri }\end{array}$} \\
\hline$\stackrel{\overparen{O}}{\stackrel{\mathscr{E}}{U}}$ & $\begin{array}{l}\stackrel{0}{\frac{\delta}{\sigma}} \\
\stackrel{+}{\leftarrow}\end{array}$ & $\begin{array}{l}\text { O } \\
\text { - }\end{array}$ & 4 & 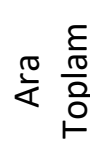 & $\frac{\frac{\varepsilon}{\pi}}{\frac{0}{0}}$ & 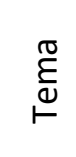 & $\begin{array}{l}\stackrel{\frac{\pi}{E}}{\oplus} \\
\frac{ \pm}{\infty}\end{array}$ & $\begin{array}{l}\text { O } \\
\text { - }\end{array}$ & 4 & $\stackrel{\frac{\varepsilon}{2}}{\frac{\delta}{0}}$ & $\frac{\frac{\varepsilon}{0}}{\frac{0}{0}}$ \\
\hline
\end{tabular}

\begin{tabular}{|c|c|c|c|c|}
\hline \multirow{10}{*}{ 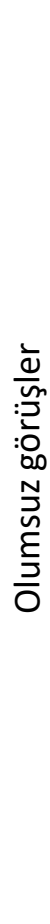 } & \multirow{5}{*}{ 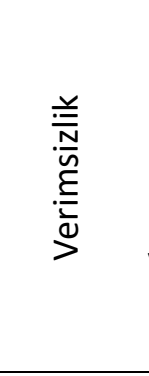 } & Ders işlenişinin yetersiz olması & 2 & \multirow[b]{5}{*}{9} \\
\hline & & Ders işlenememesi & 2 & \\
\hline & & Derslerin sıkıcı geçmesi & 2 & \\
\hline & & Videoların yavaş ve sıkıcı olması & 2 & \\
\hline & & Derslerin zevkli olmaması & 1 & \\
\hline & \multirow{4}{*}{ 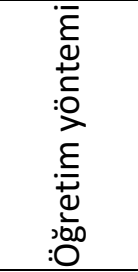 } & Öğretim elemanının sanal olması & 2 & \\
\hline & & $\begin{array}{l}\text { Ders anlatımı sırasında öğretim materyalinin } \\
\text { eksik olması/ kullanılmaması }\end{array}$ & 2 & \\
\hline & & Ezbere dayalı ders anlatılması & 1 & \\
\hline & & Öğretim yönteminin yanlış olması & 1 & 6 \\
\hline & 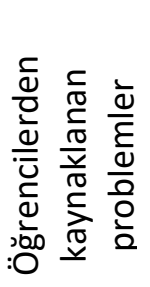 & $\begin{array}{l}\text { İnternet üzerinden öğrencilerin sadece kendi } \\
\text { istek ve arzusuyla videolara bakması } \\
\text { Ders anlatım videolarını öğrencilerin } \\
\text { izlememesi }\end{array}$ & 1 & \\
\hline
\end{tabular}

Ders işlenişinin yetersiz olması

önemsememesinin öğrencilerin derslere 3

değer vermemesine neden olması

$>$ Materyallerin genel anlamda eksik olması 2

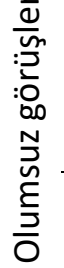

Derslerin ilkokul ve ortaokul seviyesinde anlatılıyor olması

1

Öğretim elemanının yetersiz kalması

1

হ

$\frac{\varepsilon}{\mathscr{Q}}$

O气 Öğretim elemanın dersi zorlaştırıyor olması

1 


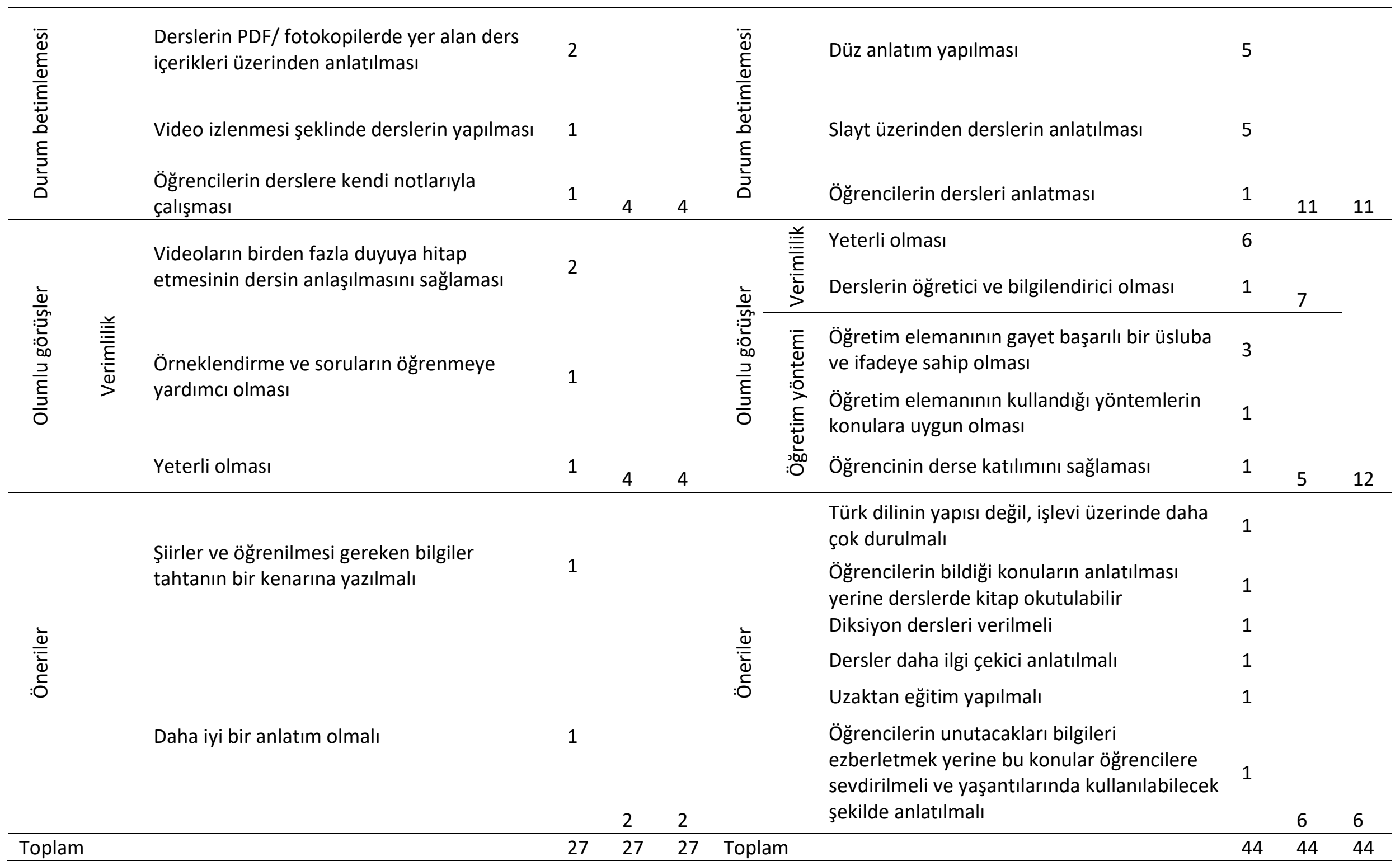


Tablo 5 incelendiğinde her iki grupta da olumsuz görüşlerin frekansı daha yüksektir. Ancak uzaktan eğitimde olumsuz görüşler, olumlu görüşlere göre yaklaşık dört kat fazlayken, yüz yüze yapılan eğitimde ise olumsuz ve olumlu görüşlerin frekansı birbirine yakındır. Bu durumun nedeni, uzaktan eğitim videolarında dersi tek bir öğretim elemanı anlatırken, yüz yüze eğitimde dersi anlatan öğretim elemanlarının farklılaşmasıdır. Çünkü öğrenciler uzaktan eğitim videolarında yer alan bir öğretim elemanıyla ilgili hiç olumlu görüş belirtmemişlerdir ancak yüz yüze eğitim alan bazı öğrenciler öğretim yöntemi alt temasında dersi veren öğretim elemanlarının ders işleyişlerini başarılı bulmakta, dolayısıyla da derslere yönelik olumlu tutum geliştirdiklerini belirtmişlerdir. Yüz yüze eğitimde öğretim elemanları dersleri konulara uygun öğretim yöntem ve teknikleri kullandıklarında öğrenciler derslerden daha memnun olduklarını ve daha iyi öğrendiklerini açıklamışlardır.

Her iki grupta yer alan öğrenciler, öğretim elemanlarının dersi önemsemediğini, bu nedenle de ders içeriğindeki konulara uygun olmayan, ezbere dayalı öğretim yöntem ve tekniklerini kullandıklarını belirtmişlerdir. Nitekim öğretim üyelerinin uzaktan eğitime olan inancı uygulamanın başarısı için önemlidir (Balaban, 2012). Türk dili dersi ile ilgili görüş belirten ve uzaktan eğitim alan öğrencilerin büyük çoğunluğu iletişim kurabilecekleri bir öğretim elemanının olmadığını, ders işlenişinin ise sıkıcı ve yetersiz olduğunu düşünmektedir. Holmberg'e göre öğretmen ve öğrenciler arasındaki iletişim, öğrenmenin temelidir. Bu iletişime katılmak öğrencinin öğrenmeden zevk almasına ve güdülenmesine neden olmaktadır (Holmberg, 1989; Akt. Karataş, 2003). Holmberg'in (1989) bulgularında da ifade edildiği gibi öğrencilerin dersi sıkıcı ve yetersiz bulmalarının bir sebebi de iletişim eksikliğidir. Ayrıca, konuşma ve dinleme becerilerini nitelikli bir şekilde geliştiremeyen bireyler sağlıklı iletişim kurma, kendini ifade etme, ana diline hâkim olma gibi konularda sorun yaşamaktadır (Akt. Yıldırım ve Kalaycı, 2020). Bu sonuç doğrultusunda öğrencilerin derslerle ilgili yaşadığı iletişim ve dinleme problemleri iş yaşantılarını etkileyebilir. Yüz yüze eğitim alan öğrenciler de benzer şekilde Türk dili dersinin yetersiz olduğunu belirtmiştir. Bu görüşlerinin nedeni ise ders içeriğinin üniversite seviyesine uygun olmadığını düşünmeleridir. Ayrıca uzaktan eğitim alan öğrenciler, zorunluluk olmadığından videoları izlemeyi tercih etmediklerini belirtmişlerdir. Bu durum öğrencilerin dersleri verimsiz bulmasından kaynaklanmaktadır. Yüz yüze eğitim alan öğrencilerden M1.4:"Zorunlu ortak derslerden verim sağlayamıyoruz. Bence bu dersler kaldırılmalı veya devam zorunluluğu olmamalı" ifadesiyle zorunluluktan dolayı derslere katıldıklarını, mecburiyet olmadığında uzaktan eğitim alan öğrencilerin yaptığı gibi derslere katılmak istemediklerini belirtmiştir.

Uzaktan eğitim alan öğrenciler, derslerde konu anlatımı içeren PDF formatındaki ders notları ve fotokopiler haricinde materyal kullanıımadığını, bu uygulamanın da öğrenme için yeterli olmadığını düşünmektedir. Yüz yüze eğitim alan öğrenciler ise derste öğretim elemanlarının anlatım yöntemini tercih ettiğini, sunu için slaytların kullanıldığını ve zaman zaman öğrenci katılımının olduğunu belirtmişlerdir. Bu derste aktif öğretim yöntemlerinin kullanılmadığı tabloda görülmektedir. Memduhoğlu ve Tanhan'a (2013) göre üniversite düzeyinde de öğrencilerin sıkılacağı, alışıla gelmiş öğretmen merkezli yaklaşım yerine, ilgi çekici ve öğrencileri merkeze alıp onu aktif kılan öğretim yöntemlerinin tercih edilmesi, çağdaş eğitim anlayışının gerektirdiği önemli bir zorunluluktur. Ancak uzaktan eğitime kıyasla yüz yüze eğitim uygulamalarında anlatım yönteminin ve slaytların kullanılması dahi öğrencilerin Türk dili dersine yönelik ilgisini artırmaktadır.

Türk dili dersinin eğitim durumuyla ilgili uzaktan eğitim alan öğrencilerin bir kısmı ders anlatımının videolarla, görsel ve işitsel olarak desteklenmesini faydalı bulmaktadır. Yüz yüze eğitim alan öğrenciler de Türk dili dersinin eğitim durumunun yeterli olduğunu düşünmektedir. Olumlu görüş belirten öğrenciler bu durumun, öğretim elemanının derslerde iyi bir öğretim yöntemi kullanmış olmasından kaynaklandığını belirtmişlerdir. Öğretim elemanlarının öğretmenlik meslek bilgisi, becerileri, alan yeterliliği ve genel kültürünün öğrencilerin akademik başarılarını etkilediğini ortaya koyan birçok araştırma vardır (Atar, 2014; Höçük, 2011).

Uzaktan eğitim alan öğrenciler, ders anlatımının daha iyi olması gerektiğini ve farklı öğretim yöntemleri kullanılmasının faydalı olacağını düşünmektedir. Çünkü uzaktan eğitim uygulamalarının niteliğinin artırılması hedeflenen başarıya ulaşmanın daha mümkün olacağı söylenebilir (Özüyürek, Bedge, Yavuz, Özkan, 2016). Yüz yüze eğitim alan öğrenciler de uzaktan eğitim alan öğrenciler gibi 
Üniversitelerdeki Zorunlu Ortak Derslerden Türk Dili Dersinin Uzaktan ve Yüz Yüze Eğitim Uygulamalarının Karşılaştırılarak Değerlendirilmesi

farklı öğretim yöntemleri kullanılması gerektiği görüşüne sahiptir. Yüz yüze eğitim alan öğrenciler bu yöntemleri daha ilgi çekici, ezbere yönelik olmayan yöntemler şeklinde ifade etmişlerdir.

\section{Ölçme ve Değerlendirme;}

Zorunlu ortak dersleri yüz yüze ve uzaktan eğitim uygulaması ile alan öğrencilerin Türk dili dersinin ölçme ve değerlendirmesi ile ilgili görüşleri Tablo 6' te yer almaktadır. 
Tablo 6.

Zorunlu Ortak Dersleri Uzaktan ve Yüz Yüze Eğitim Uygulaması Yoluyla Alan Öğrencilerin, Türk Dili Dersinin Ölçme ve Değerlendirmesi Ile IIlgili Görüşlerinin Karşılaştırılması

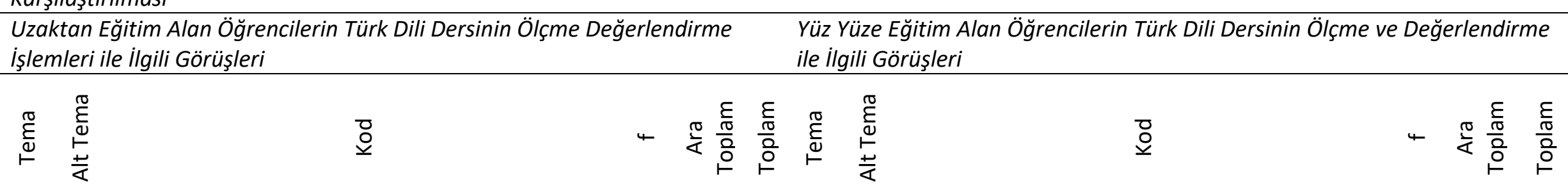

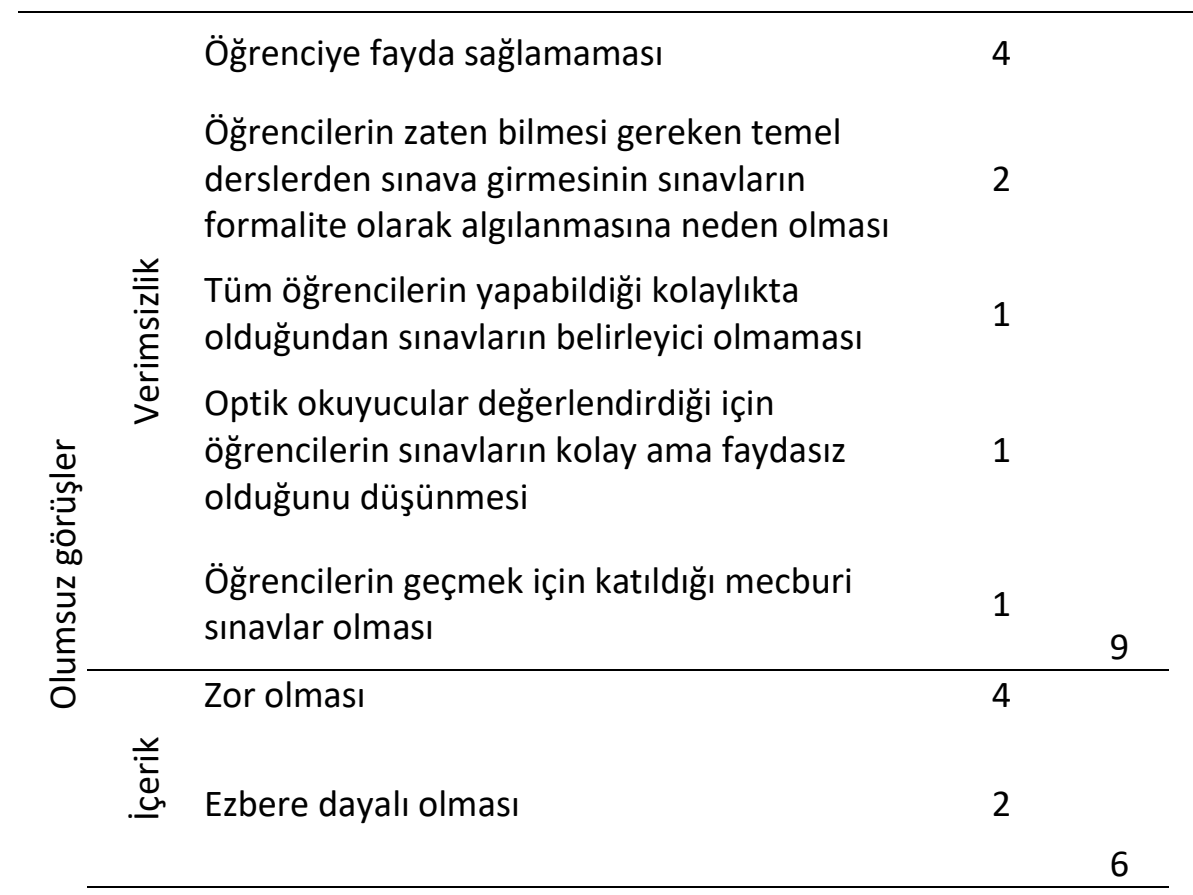

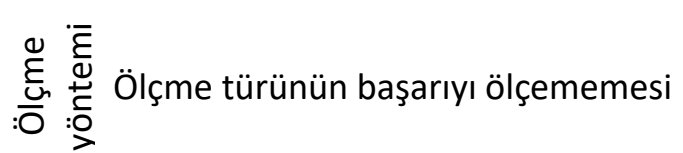

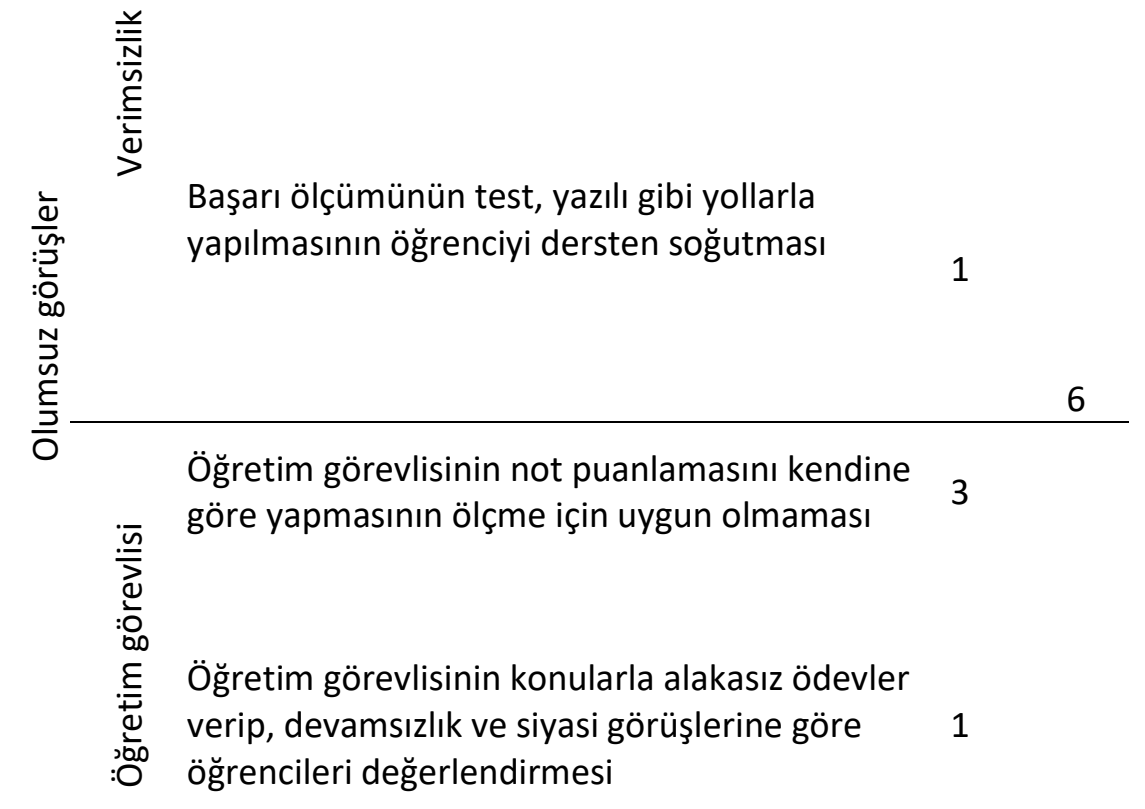




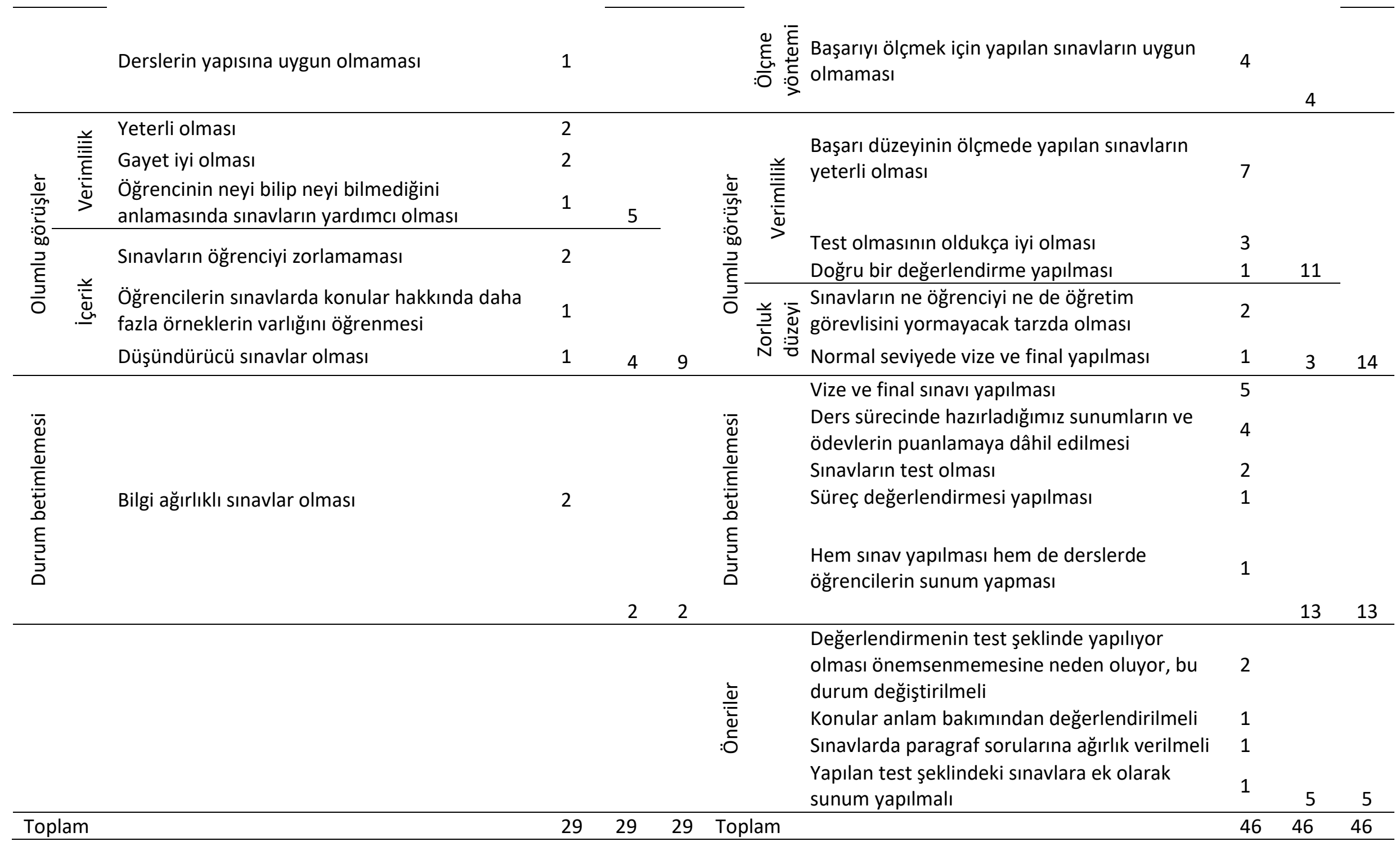


Tablo 6'daki veriler incelendiğinde uzaktan eğitimde öğrencilerin olumsuz görüşlerinin frekansı olumlu görüşlerine göre iki kat fazla iken, yüz yüze eğitimde bu görüşlerin frekansları eşittir. Ancak her iki grupta da hem olumlu hem olumsuz görüşlerin ortak nedeni sınavların kolay olmasıdır. Bu durum sınavların belirleyici olmamasına ve derslerin de sınavların da formalite olarak algılanmasına neden olmaktadır. Ayrıca öğrenciler, sınavların yetersiz olduğu ve yalnızca test veya yazılılarla başarı düzeylerinin ölçülemeyeceğini düşünmektedir.

Her iki gruptaki öğrencilerin bir kısmı da uygulanan ölçme yönteminin öğrencinin bilgi düzeyini ölçmede yeterli olduğunu ve öğrencinin bilmediği bilgileri ayırt edebilen doğru bir yöntem tercih edildiğini düşünmektedir. Uzaktan eğitim alan öğrenciler sınavların kendilerini zorlamayan, düşündürücü sorulardan oluştuğunu belirtmişlerdir. Yüz yüze eğitim alan öğrenciler ise ölçme ve değerlendirmeye yönelik soruların ne kendilerini, ne de öğretim görevlisini yormayacak kolaylıkta olduğunu belirtmiştir. Olumlu görüşler incelendiğinde öğrencilerin bu görüşlerinin temel nedeninin, doğru bir ölçme yapılmasından kaynaklanmadığı, öğrencilerin az bir çalışmayla veya hiç çalışmadan sadece ortaöğretim bilgileriyle sınavları geçebilmelerinden kaynaklandığı ortaya çıkmaktadır. Çünkü bu durumla ilgili H4.7: "Sınavları hiç çalışmadan geçiyoruz. Çünkü bu konuları üniversite öncesinde öğrenmiştik." ifadesiyle sınavlara çalışma gereği duymadığını ifade etmiştir. Ancak öğrencilerin ifade ettiği bu durum öğrenciler memnuniyet duysalar da doğru bir ölçme yapılmadığını ortaya koymaktadır. Çünkü çağdaş eğitim sistemlerinde ölçme ve değerlendirmeye bir öğrencinin var olan durumunun belirlenmesi ve değer biçmekten öte bir işlev yüklenmekte; ölçme ve değerlendirme öğrencinin öğrenmeyi biçimlendirme (formative assessment) ve istenilen hedefe ulaşılmasına yardımcı olma görevi görmektedir (Bozkurt, 2017).

Uzaktan eğitim alan öğrenciler, düşük puanla geçilen ve bilgi ağırlıklı (ezber gerektiren) sınavlar yapıldığı görüşüne sahiptir. Yüz yüze eğitim alan öğrenciler ise bazı öğretim görevlilerinin vize ve final sınavı yaparken, bazılarının da sınava ek olarak verdikleri ödevlerle bir süreç değerlendirmesi yapıldığını belirtmiştir.

Öğrenciler, sınavların sadece test şeklinde yapılmaması gerektiği, süreç değerlendirmesinin de yapılması önerisinde bulunmuşlardır. Bazı uzaktan eğitim programlarında, farklı bir değerlendirme yöntemi olarak öğrenciler, final sınavı yerine araştırma tabanlı proje raporları hazırlamaktadırlar (Moore ve Kearsley, 2011). Ayrıca öğrenciler sınav içeriklerinin de düzenlenmesi gerektiğini düşünmektedir.

\section{Zorunlu Ortak Derslerin Uzaktan ve Yüz Yüze Eğitim Uygulamalarının Avantaj ve Dezavantajları}

Uzaktan eğitim uygulaması, yüz yüze eğitim ile karşılaştırıldığında uzaktan eğitimin avantajları ve dezavantajları hakkında ki öğrenci görüşleri Tablo 7'da sunulmaktadır.

Tablo 7.

Uzaktan Eğitim Uygulaması, Yüz Yüze Eğitim Ile Karşılaştırıldığında Uzaktan Eğitimin Avantajları ve Dezavantajlarıyla ilgili Öğrenci Görüşleri

\begin{tabular}{|c|c|c|c|c|c|}
\hline 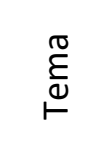 & 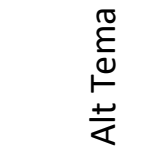 & $\underset{\ddot{D}}{\ddot{0}}$ & $\leftarrow$ & $\stackrel{\frac{\pi}{\alpha}}{\frac{\varepsilon}{0}} \frac{\varepsilon}{0}$ & $\begin{array}{l}\frac{\varepsilon}{\sigma 0} \\
\frac{0}{0} \\
0\end{array}$ \\
\hline \multirow{9}{*}{ 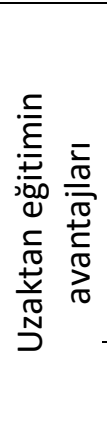 } & \multirow{7}{*}{$\begin{array}{l}\text { Eğitim } \\
\text { durumu }\end{array}$} & Devamsızlık probleminin olmaması & 10 & & \\
\hline & & Her zaman eğitim imkânı sağlaması & 7 & & \\
\hline & & Evde, günlük kıyafetle ders dinleme imkanının olması & 6 & & \\
\hline & & Videoların tekrar izlenebilmesi & 4 & & \\
\hline & & Ders yapılamaması (teknik sorunlar nedeniyle) & 4 & & \\
\hline & & Daha çok kişiye aynı anda eğitim imkânı sağlaması & 2 & & \\
\hline & & Anlatımın yalın olması & 1 & 34 & \\
\hline & \multirow{2}{*}{$\begin{array}{l}\text { Zaman } \\
\text { tasarrufu }\end{array}$} & Üniversiteye gitmek için yolda zaman kaybedilmemesi & 14 & & \\
\hline & & Öğrencilerin daha fazla boş vakit kazandırması & 9 & 27 & 77 \\
\hline
\end{tabular}




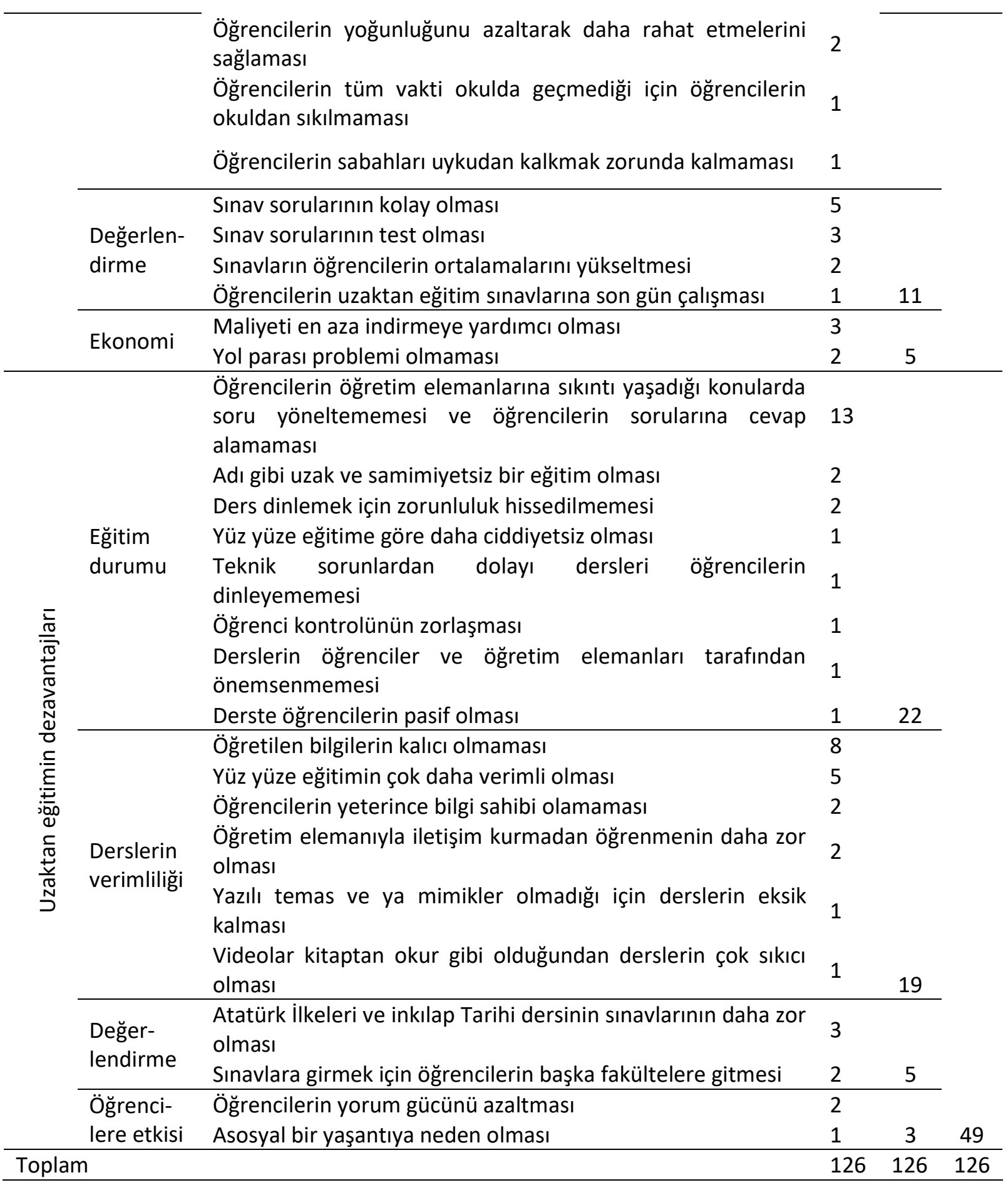

Öğrencilerin büyük bir çoğunluğu uzaktan eğitim uygulamasının yüz yüze eğitim uygulamasına göre daha avantajı olduğunu düşünmektedir. Öğrenciler uzaktan eğitimi avantajı bulma nedenlerini; derslerde devamsızlık probleminin olmaması, kendilerine daha fazla vakit ayırabilmeleri, istedikleri zaman, istedikleri kadar ders videolarını izleyebilmeleri şeklinde sıralamışlardır. Bu bulgu Balaban (2012:24) tarafından yapılan araştırmada da "Uzaktan eğitim ile öğrenci, istediği konularla ilgili kaynaklara ulaşarak, istediği zamanda ve istediği kadar tekrar yapabilme olanağına sahip olabilmektedir." şeklinde yer almaktadır.

Öğrenciler, uzaktan eğitim uygulamalarında derse gitmek için yolda vakit kaybetmediklerinden, derslere katılabilmek için para harcamadıklarından bu uygulamanın avantajlı olduğunu düşünmektedir. Çünkü uzaktan eğitimde, fiziksel olarak bir buluşma noktası olmadığından 
dolayı; bu eğitim yol, konaklama ve kişisel giderler gibi maddi yükümlülükler getirmemektedir (Höçük, 2011). Ayrıca öğrenciler sınav sorularının kolay ve test şeklinde olmasını da bir avantaj olarak belirtmektedir. Bu durumla ilgili öğrencilerden bazıları şu şekilde görüş belirtmişlerdir: F2: "Derse gitmek için yolda vakit kaybetmiyorum.", M4: "Yolda boşa zaman harcanmıyor. Oturduğumuz yerden dersi dinleyebiliyoruz.", F4: "Test olarak soruların çıkması bir avantajdır."

Öğrenciler, sorularının basit test sorularından oluştuğunu ve bu durumun genel akademik not ortalamalarını yükselttiğini belirtmişlerdir.

Öğrencilerin uzaktan eğitimle ilgili en çok görüş belirttiği dezavantaj öğretim elemanlarına sorun yaşadıkları konularda soru yöneltememektir. Bu durum öğrencilerin yüz yüze eğitimi daha verimli bulmasına neden olmaktadır. Ayrıca uzaktan eğitim alan öğrenciler, derslere devam zorunluluğu bulunmadığından dersleri izleme zorunluluğu hissetmemekte, bunun sonucunda da uzaktan eğitimden fayda sağlayamamaktadır. Çünkü uzaktan eğitim kapsamında sözü edilen yararların rolü her ne kadar büyük olsa da, başarıda belirleyici öge, sistemi kullanan kişilerdir (Savaş, 2007). Ayrıca, öğrenciler, uzaktan eğitim derslerini yeterinde ciddi bulmamakta ve yeterince bilgi sahibi olamadıklarını düşünmektedir. Öğrenciler, uzaktan eğitimde öğrenmenin zor gerçekleştiğini ve öğrenilen bilgilerin de kalıcı olmadığını düşünmektedir. Sınavlara farklı fakültelerde girmek öğrenciler açısından problemlere neden olmaktadır.

Uzaktan eğitimde derslere internet üzerinden katılım sağlandığından öğrenciler, bu durumun sosyalleşememelerine neden olduğunu düşünmektedir. Özer (2011) tarafından yapılan araştırmanın bulgularında da öğrenciler, uzaktan eğitim programlarının en büyük eksikliğinin iletişim sorunu olduğunu belirtmişlerdir. Öğrenciler, hem öğretmen hem de öğrenci arkadaşlarıyla yeterli iletişimi sağlayamadıklarını, bu durumun sonucu olarak sosyalleşmede de sorun yaşadıklarını düşünmektedirler.

Uzaktan eğitim uygulamasını, yüz yüze eğitim ile karşılaştırdığımızda yüz yüze eğitimin avantajları ve dezavantajları hakkındaki öğrenci görüşleri Tablo 8'de sunulmaktadır.

Tablo 8 .

Uzaktan Eğitim uygulaması, Yüz Yüze Eğitim ile Karşılaştırdığımızda Yüz Yüze Eğitimin Avantajları ve Dezavantajlarıyla ilgili Öğrenci Görüşleri

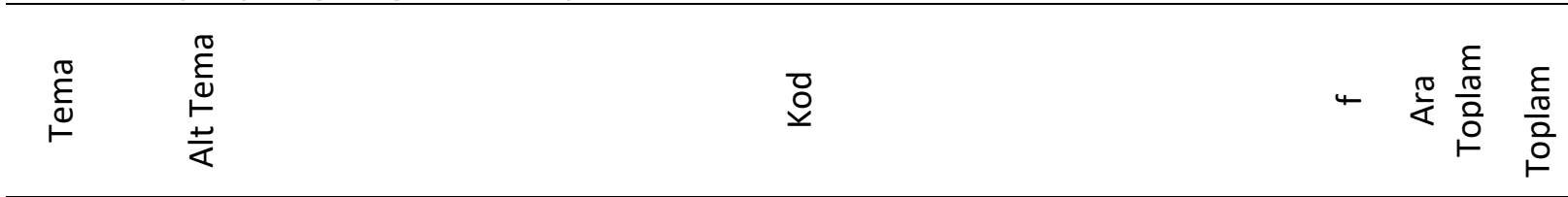

\begin{tabular}{|c|c|c|c|}
\hline \multirow{4}{*}{ İletişim } & $\begin{array}{l}\text { Derslerin karşılıklı etkileşim içerisinde işlenmesinin daha verimli } \\
\text { olması }\end{array}$ & 10 & \\
\hline & $\begin{array}{l}\text { Öğrencilerin sorularına hızı bir şekilde cevap almasının başarıyı } \\
\text { arttırması }\end{array}$ & 5 & \\
\hline & Bu eğitimde anında dönüt alınabilmesi & 1 & \\
\hline & $\begin{array}{l}\text { Derslerde anlaşılamayan konularda öğrencilerin öğretim } \\
\text { elemanından hızlı bir şekilde yardım alabilmesi }\end{array}$ & 1 & 17 \\
\hline \multirow{4}{*}{$\begin{array}{l}\text { Derslerin } \\
\text { verimliliği }\end{array}$} & Derslerde öğrenilen bilgilerin daha akılda kalıcı olması & 7 & \\
\hline & Derslerde daha rahat konsantrasyon sağlanması & 2 & \\
\hline & Derslerin öğrencileri motive ediyor olması & 1 & \\
\hline & $\begin{array}{l}\text { Dersler esnasındaki sesli ve görsel öğelerin öğrenmede etkili } \\
\text { olması }\end{array}$ & 1 & $I$ \\
\hline
\end{tabular}


Üniversitelerdeki Zorunlu Ortak Derslerden Türk Dili Dersinin Uzaktan ve Yüz Yüze Eğitim Uygulamalarının Karşılaştırılarak Değerlendirilmesi

lere etkisi

Bu derslerin öğrencilere üniversitede olduklarını hissettirmesi 1

\begin{tabular}{|c|c|c|c|c|c|}
\hline \multirow{11}{*}{ 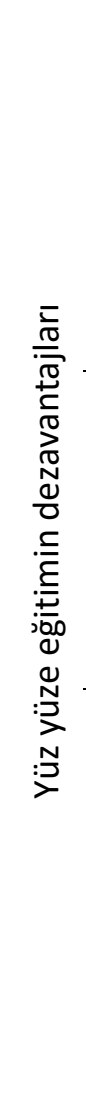 } & \multirow{5}{*}{$\begin{array}{l}\text { Eğitim } \\
\text { durumu }\end{array}$} & Devamsızlığın problem olması & 4 & & \\
\hline & & Zaman kaybına neden olması & 4 & \multirow{4}{*}{11} & \\
\hline & & Maddi olarak külfetli olması & 1 & & \\
\hline & & Ders saatlerinin kişiye göre esnek olmaması & 1 & & \\
\hline & & $\begin{array}{l}\text { Dinleyici davranışlarının konunun dağılmasına ve gereksiz } \\
\text { tekrarlara sebep olabilmesi }\end{array}$ & 1 & & \\
\hline & \multirow{3}{*}{$\begin{array}{l}\text { Değer- } \\
\text { lendirme }\end{array}$} & $\begin{array}{l}\text { Sınavların ezbere dayalı olması ve soruların yoruma açık } \\
\text { olmaması }\end{array}$ & 2 & & \\
\hline & & $\begin{array}{l}\text { Bazı öğretim elemanlarının ödev vererek değerlendirme } \\
\text { yapılması }\end{array}$ & 1 & & \\
\hline & & $\begin{array}{l}\text { Test olarak yapılan sınavlardan çoğu öğrencinin mantığa dayalı } \\
\text { cevaplar vererek geçer not alabilmesi }\end{array}$ & 1 & 4 & \\
\hline & \multirow{3}{*}{$\begin{array}{l}\text { Öğretim } \\
\text { elemanı }\end{array}$} & $\begin{array}{l}\text { Öğrencilerin, öğretim elemanlarının kendilerine karşı fazla ön } \\
\text { yargılı davrandıklarını ve kendilerini objektif olarak } \\
\text { değerlendirmediklerini düşünmesi }\end{array}$ & 1 & & \\
\hline & & $\begin{array}{l}\text { Öğretim elemanının mesleki yeterliliğine göre dersin } \\
\text { verimliliğinin değişebilmesi }\end{array}$ & 1 & & \\
\hline & & $\begin{array}{l}\text { Mesleki yeterliliğe sahip olmayan öğretim elemanlarının } \\
\text { derslerde fayda sağlanamamasına neden olması }\end{array}$ & 1 & 3 & 18 \\
\hline \multicolumn{2}{|c|}{ Toplam } & & 48 & 48 & 48 \\
\hline
\end{tabular}

Yüz yüze eğitim, uzaktan eğitim uygulaması ile karşılaştırıldığında yüz yüze eğitim alan öğrencilerin büyük bir çoğunluğu yüz yüze eğitim uygulamasının daha avantajlı olduğunu düşünmektedir. Tablo 7 ve Tablo 8' de yer alan veriler birlikte değerlendirildiğinde, öğrenciler zorunlu ortak derslere hangi eğitim uygulaması ile katıldıysa o eğitim uygulamasının daha avantajlı olduğunu ifade etmişlerdir. Başka bir ifade ile uzaktan eğitim uygulamasına katılan öğrenciler, uzaktan eğitim uygulamasının; yüz yüze eğitim uygulamasına katılan öğrenciler de yüz yüze eğitim uygulamasının avantajlı olduğunu düşünmektedir.

Öğrencilerin en çok görüş belirttiği yüz yüze eğitimin avantajları temasında öğrenciler, derslerin öğretim elemanı ile etkileşimli şekilde işlendiğini ve bu durumun öğrenmeleri açısından daha faydalı olduğunu ifade etmişlerdir. Bu nedenlerden ötürü yüz yüze eğitimin avantajlı olduğu yönünde görüş belirtmişlerdir.

Öğrenciler, yüz yüze eğitim ile öğrenilen bilgilerin daha kalıcı olduğunu belirtmektedir. Ersoy (2015:105) tarafından yapılan araştırmada da "öğrencilerin çoğunun uzaktan eğitimi etkili bir uygulama olarak görmedikleri ve sınıf ortamında yüz yüze öğrenim görmek istedikleri" belirlenmiştir. Görüş belirten öğrencilerden E4.12: "Derste yorum yapılır, fikirler öne sürülür. Merak edilen sorular sorulur. Öneriler alınır ve birçok avantajı vardır.", H4.2: "Öğretim elemanı ve öğrencilerin tartışmaları eğitim ve öğrenme için daha yararlı olur. Anında soru-cevapla daha yüksek başarı elde edilebilir.", E4.14: "Dersi dinlemek bile konuların akılda kalmasında oldukça faydalı arada sorulan sorularla daha da pekişiyor." ifadeleriyle yüz yüze eğitimin avantajlarını dile getirmişlerdir.

Öğrenciler, yüz yüze eğitimde zaman kaybı yaşadıklarını düşünmektedir. Öğrenci görüşleri incelendiğinde bu durumun iki nedeni olduğu belirlenmiştir. Bunlardan birincisi derslere devam 
zorunluluğu olması, ikincisi ise bu eğitim uygulamasının kişiye göre esneklik göstermemesidir. Ayrıca öğrenciler, yüz yüze eğitim uygulamasında maddi zorluk yaşadıklarını da belirtmişlerdir. Yüz yüze eğitimle ilişkili olarak öğrencilerin belirttiği bir diğer dezavantaj ise ders esnasında yaşanan olumsuzluklardır. Öğrenciler bu durumun konuların gereksiz tekrarına ve derslerin uzamasına neden olabildiğini belirtmiştir.

Öğrenciler, basit sorulardan oluşan çoktan seçmeli sınavların yapıldığını düşünmektedir. Ayrıca öğrenciler, öğretim elemanına göre derste sağlanan verimin değişebildiği ve öğretim elemanının bir öğrenciye karşı oluşan önyargısının sınav sonucunu etkileyebildiği düşüncesine sahiptir. Nitekim öğrencilerin de belirttiği gibi derslerde yapılan ölçme ve değerlendirmeler genellikle öznel biçimde yapılmaktadır. Bunun neticesinde alınan sonuçlar öznel biçimde değerlendirilmektedir (Callı, Torkul ve Taşbaşı, 2003).

\section{Tartışma ve Sonuç}

Yukarıdaki bulguların genel bir özeti şöyledir:

Ders içeriği boyutunda, iki gruptaki öğrencilerin de olumsuz görüşlerinin nedenleri ortaktır ve bu görüşler Türk dili ders içeriğinin zorluk düzeyi ile ilgilidir. Öğrenciler bu dersin içeriğinin üniversite öncesindeki ortaokul ve lise kademesinde öğrendikleri konulardan oluştuğunu ve bu nedenle hali hazırda öğrenim gördükleri sınıf düzeyine göre basit olduğunu belirtmektedir. Ayrıca, Türk dili dersinin içeriğinde yer alan bazı konuların uzaktan eğitimle verilmesinin uygun olmadığı düşünülmektedir.

Ders işlenişi (eğitim durumu) boyutunda, her iki grupta da olumsuz görüşler çoğunluktadır ve nedenlerinin bir kısmı ortaktır. Bu boyuta ilişkin olumsuz görüşler çoğunlukla ders tasarımının ve kullanılan materyallerin yetersiz olduğu yönündedir. Öğrencilerin bu düşüncelerinin nedeni öğretim elemanlarının konuya uygun öğretim yöntem ve teknikleri kullanmamasından kaynaklanmaktadır. Öğretim elemanları dersleri konulara uygun öğretim yöntem ve tekniklerle işlediklerinde öğrenciler derslerin daha verimli geçtiğini belirtmişlerdir.

Ölçme ve değerlendirme boyutunda, her iki grupta da olumsuz görüşler çoğunluktadır ve nedeni sınavların kolay olmasıdır. Ancak bu durum bazı öğrenciler tarafından olumlu bir durum olarak da algılanmaktadır. Nitekim her iki durumda da bu sınavların belirleyici olmamasına ve hem derslerin hem de sınavların öğrenciler tarafından formalite olarak algılanmasına neden olmaktadır. Ayrıca öğrenciler, yalnızca çoktan seçmeli veya açık uçlu sorularla başarı düzeylerinin ölçülemeyeceğini, yapılan sınavların başarılarını ölçmek için yetersiz olduğu düşünmektedir.

Tüm eğitim kademelerinde özellikle de üniversitelerde bilgiye kolay erişebilen, onu kullanıp üretimine katkı sağlayabilen, eleştirel ve yaratıcı düşünme becerilerine sahip olan, kendisini sürekli geliştiren, evrensel ve ulusal değerleri özümsemiş bireylerin (Saraçaloğlu ve Kaşlı, 2001) yetiştirilmesi amaçlanmaktadır. Dünyadaki teknoloji kullanımının artmasıyla birlikte bireylerden beklenen bu beceri ve değerlerin kazandırımasında teknolojinin kullanımı önemli hale gelmiştir. Bu nedenle uzaktan eğitim çalışmaları 1950'lerde başlamıştır. Ancak süreç biraz yavaş ve ilgiden yoksun ilerlemiştir. Hızlı bir şekilde artan nüfusa, nitelikli ve etkili bir eğitim hizmeti sunabilmek için artık yüz yüze eğitimin tek başına yeterli olmadığını düşünen ülkeler, beklentilere cevap verebilecek en ideal eğitim uygulamalarından biri olan uzaktan eğitime yönelmişlerdir. Uzaktan eğitimin popülerliğini artıran en önemi etkenlerden birisi 2008 yılında MOOC (Massive Open Online Course) öğretim uygulamalarının kullanılmaya başlanmasıdır. Dünyada MOOC'larla çok başarılı uzaktan eğitim derslerinin yapılması ülkemizde de bu uygulamanın etkili bir eğitim uygulaması olarak kullanılabileceği fikrini pekiştirmiştir. Yüz yüze eğitim uygulamasına göre birçok avantajıyla dikkat çeken uzaktan eğitim, ancak doğru tasarlandığında ve uygulandığında etkili bir öğretim uygulamasıdır. Çünkü Anadolu Üniversitesi gibi 1982 yılında başlayan ve uzaktan eğitimi başarılı bir şekilde yürüten örnekler olsa da uygulamanın kendisinden, uygulayıcılardan ve hedef kitleden kaynaklanan olumsuzluklar, uzaktan eğitimde birçok sorun yaşanmasına neden olmaktadır. Bu sorunları somutlaştırmak gerekirse; internet bağlantısının olmaması, bilgisayar ya da akıllı telefon vb. araçların bulunmaması, öğrencilerin ders dinlemedeki motivasyon düşüklüğü, derslerin senkron olmaması, öğretim tasarımının nitelikli bir şekilde yapılmaması, uzaktan eğitimi yürüten öğretim 
elemanlarının isteksizliği ve yetersizliği gibi sorunlardır. Yaşanan bu problemler öğrencilerin uzaktan ve yüz yüze eğitim algısını olumsuz etkilemekte ve özellikle yeni karşılaştıkları uzaktan eğitimi verimsiz bir öğretim uygulaması olarak algılamalarına sebep olmaktadır. Zorunlu ortak derslerle ilgili bu problemler çözülmedikçe hangi öğretim uygulaması kullanılırsa kullanılsın öğrenciler Türk dili derslerine karşı olumsuz tutumlarını devam ettirecekler ve Türk dili dersini üniversite eğitim programlarında yer alan gereksiz dersler olarak algılayacaklardır. Bu nedenle uzaktan eğitim veren kurumlar teknolojiyi yakından takip etmeli, öğrencilerine standart bir öğretim hizmeti sunmaktan kaçınarak, öğrencileri memnun edecek daha etkili hizmetler sunabilmelidir (Eygü ve Karaman, 2013).

Üniversite bünyesindeki UZEM gibi merkezlerdeki fiziki alt yapının teknolojik ve finans olarak desteklenmesi gerekmektedir. Ayrıca bu merkezlerde program geliştirme uzmanı, eğitim psikoloğu, sosyoloğu, teknoloğu, ölçme ve değerlendirme uzmanı, sanat yönetmeni, video ve ses tasarımcısı, animasyon gereksinimlerini karşılayacak programcıların yer alması öğretim tasarımlarının niteliği açısından son derece önemli ve gereklidir. Bu COViD-19 pandemi sürecinde de üniversitelerin uzaktan eğitim merkezlerinin önemi bir kez daha anlaşılmıştır. Ayrıca yüz yüze eğitimle harmanlanmış şekilde yeniden düzenlenen uzaktan eğitim uygulamaları üniversiteler için geleceğe yapılacak en önemli yatırımdır. Üniversiteler bu gerçek doğrultusunda çalışmalarını yürütmelidir. Öğretim elemanları da mesleklerinin ihtiyaç duyduğu yeni teknolojik becerileri kazanmalı, sürekli kendilerini geliştirecek çözümlere yönelmeli, yaşam boyu öğrenme kültürünü benimsemeli ve öğrendikleri bu teknolojik bilgileri mesleklerine transfer edebilmelidir. Öğrenciler de uzaktan eğitim uygulamalarına katılmaya istekli olmalıdır. Çünkü eğitim bir iletişim sürecidir. Tek başına eğitimcinin veya öğrencinin olduğu bir süreç değildir. Her ne kadar uzaktan eğitim olsa dahi özellikle eşzamanlı (senkron) eğitimlerde iletişim süreci nitelikli bir şekilde gerçekleşmelidir.

Zorunlu ortak derslerden Türk dili dersi, yalnızca 5 ı dersi değildir. İnsanın anadili bireyin ruhsal edinimlerini şekillendiren, bilgilerini, duygularını ve kültürünü biçimlendiren bir araçtır. Bu nedenle Türk dilini öğrencilerin kusursuz bir şekilde öğrenmesi, milli şuura sahip öğrencilerin yetiştirilebilmesi açısından üniversitelerin en önemli görevi olmalıdır. Atatürk'ün söylediği gibi: "Milli his ile dil arasındaki bağ çok kuvvetlidir. Türk dili, Türk milletinin kalbidir, zihnidir."

\section{Kaynaklar}

Akkaya, N. ve Sevindi, Z. E. (2015). Üniversitelerde okutulan ortak zorunlu Türk dili derslerine yönelik tutum ölçeği geliştirme. Buca Eğitim Fakültesi Dergisi, 39, 92-103.

Atar, H. Y. (2014). Öğretmen niteliklerinin TIMSS 2011 fen başarısına çok düzeyli etkileri. Eğitim ve Bilim Dergisi, 39(172), 121-137.

Aubusson, P. ve Schuck, S. (2013). Teacher education futures: Today's trends, tomorrow's expectations. Teacher Development, 17(3), 322-333.

Balaban, E. (Şubat, 2012). Dünyada ve Türkiye'de uzaktan eğitim ve bir proje önerisi. Işık Üniversitesi, İstanbul.

Bozkurt, B.Ü. (2017). Türkçe anadili konuşucuları için konuşma becerisi değerlendirme çerçevesi önerisi. Ana Dili Eğitimi Dergisi, 5(4), 924-947.

Büyüköztürk, Ş., Kılıç Ç., E., Akgün, Ö. E., Karadeniz, Ş. ve Demirel, F. (2013). Bilimsel araştırma yöntemleri. Ankara: Pegem Yayınları.

Callı, İ., Torkul, O. ve Taşbaşı, N. (2003). İnternet Destekli Öğretimde Kullanılmak üzere Web Erişimli Veri Tabanı Yönetim Sistemiyle Ölçme ve Değerlendirme Sistemi Tasarımı. The Turkish Online Journal of Educational Technology, 2(3), 108-115.

Cemiloğlu, M. (2004). Üniversitelerde okutulan Türk dili dersi ile ilgili tespitler değerlendirmeler ve öneriler. Eğitim Fakültesi Dergisi, 17(2), 173-182.

Demir, C. ve Yapıcı, M. (2007). Ana dili olarak Türkçenin öğretimi ve sorunları. Sosyal Bilimler Dergisi, 9(2), 177-192.

Ersoy, N. Ş. (2015). Uzaktan İngilizce dersinin farklı değişkenler açısından incelenmesi. Eğitim ve Öğretim Araştırmaları Dergisi, 4(3), 95-106. 
Eygü, H. ve Karaman, S. (2013). Uzaktan eğitim öğrencilerinin memnuniyet algıları üzerine bir araştırma. Sosyal Bilimler Araştırma Dergisi, 3(1), 36-59.

Fırat, M. (Ağustos, 2016). 21. yüzyılda uzaktan öğretimde paradigma değişimi. Yükseköğretim ve Bilim Dergisi, 6(2), 142-150.

Gazi Üniversitesi. (2018). Zorunlu ortak derslerin ve kredilerin dağılımı. http://guzem.gazi.edu.tr/posts/view/title/yok-5\%28i\%29-ortak-dersleri115157?siteUri =guzem sayfasından erişilmiştir.

Göğüş, B. (1983). Orta dereceli okullarımızda Türkçe ve yazın eğitimi, Ankara.

Guba, E. G. ve Lincoln, Y. S. (1994). Competing paradigms in qualitative research. Handbook of qualitative research, 2(105), 163-194.

Harvey, L., ve Green, D. (1993). Defining quality. Assesment and Evaluation in Higher Education, 18(1), 9-26.

Höçük, S. (2011). Ankara üniversitesi uzaktan eğitim programına katılan öğrencilerin akademik başarılarını etkileyen faktörler. Yüksek Lisans Tezi, Ankara Üniversitesi Eğitim Bilimleri Enstitüsü, Ankara.

Kan, A. Ü. ve Fidan, E. K. (Mayıs, 2016). Türk dili dersinin uzaktan eğitimle yürütülmesine ilişkin öğrenci algıları. Turkish Journal of Educational Studies, 3(2), 23-45.

Kalaycı, N. ve Yıldııım, N. (2020). Türkçe dersi öğretim programlarının karşılaştırmalı analizi ve değerlendirilmesi (2009-2017-2019). Trakya Eğitim Dergisi, 10(1), 238- 262.

Karataş, M. (2013). Üniversitelerdeki Türk dili dersi ve Türkçe konusundaki tutumlar. Literature and History of Turkish or Turkic, 8(1), 1881-1898.

Karataş, S. (2003). Yüz yüze ve uzaktan eğitimde öğrenme deneyimlerinin eşitliği. Eğitim Bilimleri ve Uygulama, 2(3), 91-104.

Klenke, K. (2016). Qualitative research in the study of leadership. Emerald Group Publishing Limited.

Korkmaz, M., Kalkan, N., Doğan, A., Doğruluk, M. ve Aydın, C. Ç. (IVSS 2018). Hacettepe Üniversitesi'nde uzaktan eğitim yöntemi ile okutulan Türk dili derslerinin başarı oranlarının ön lisans ve lisans programlarında karşılaştırılması. International Vocational Science Symposium, Antalya, 2-9.

Marczyk, G., DeMatteo, D. ve Festinger, D. (2005). Essentials of research design and methodology. New York: John Wiley \& Sons Inc.

Memduhoğlu, H. B. ve Tanhan, F. (2013). Üniversite öğrencilerinin akademik başarılarını etkileyen örgütsel faktörler ölçeğinin geçerlik ve güvenirlik çalışması. Yüzüncü Yıl Üniversitesi Eğitim Fakültesi Dergisi, 10(1), 106-124.

Moore, M. G. ve Kearsley, G. (2011). Distance education: A systems view of online learning. (3rd ed.). Belmont: Wadsworth.

Miles, M. B., Huberman, A. M. ve Saldana, J. (2013). Qualitative data analysis: A methods sourcebook. Los Angeles:Sage.

Onan, B. (2012). Dil eğitiminin dil bilimsel temelleri: Ferdinand de Saussure'ün genel dilbilim kuramında dil eğitimiyle ilgili bulgular. Mustafa Kemal Üniversitesi Sosyal Bilimler Enstitüsü Dergisi, 9(17), 219-243.

Onan, B. (2017). Ana dili öğretiminde yapılandırmacı hedefler üzerine bir tasnif çalışması. Ana Dili Eğitimi Dergisi, 5(4), 806-822.

Önkaş, N. A. (2010). Ana dili öğretimine yeni yaklaşımlar. Sosyal Bilimler Enstitüsü Dergisi, Muğla Üniversitesi, 24, 121-128.

Özer, B. (2011). Uzaktan eğitim programlarının öğrenci ve öğretim üyesi görüşleri açısından değerlendirilmesi (Sakarya üniversitesi örneği). Yüksek Lisans Tezi, Abant İzzet Baysal Üniversitesi Eğitim Bilimleri Enstitüsü, Bolu.

Özüyürek, A., Bedge, Z., Yavuz, N. F. ve Özkan i. (2016). Uzaktan eğitim uygulamasının öğrenci bakış açısına göre değerlendirilmesi. Karabük Üniversitesi Sosyal Bilimler Enstitüsü Dergisi, 6(2), 583-596.

Tezcan, N. (1983). Yüksek Öğretimde Anadili Öğretimi, Türk Dili, Ankara. 
Saraçaloğlu, A. S. ve Kaşlı, A. (2001). Öğretmen adaylarının bilgisayara yönelik tutumları ile başarıları arasındaki ilişki. Ege Eğitim Dergisi, 1(1), 112-127.

Savaş, S. (2007). Web tabanlı uzaktan eğitimde iki farklı öğretim modelinin öğrenci başarısı üzerindeki etkilerinin incelenmesi. Yüksek lisans tezi, Gazi Üniversitesi Bilgi ve iletişim Enstitüsü, Ankara.

Sever, S. (2002). Bir öğretim dili olarak Türkçenin sorunları ve öğretme-öğrenme sürecindeki etkili yaklaşımlar. Türkçenin Dünü, Bugünü, Yarını Uluslarası Bilgi şöleni, Ankara, Kültür Bakanlığı, 185-204.

Walker, J. L. (2012). The use of saturation in qualitative research. Canadian Journal of Cardiovascular Nursing, 22(2), 37-46.

Vural, H. (2007). Üniversitelerde okutulan Türk dili dersi üzerine, Dil ve Edebiyat Dergisi, 93(669), 496-503.

Yangın, B. (2001). Illköğretimde Türkçe öğretimi, ilköğretimde etkili öğretme ve öğrenme, öğretmen el kitabı, Ankara: MEB.

Yükseköğretim Kurulu [YÖK]. (2018). Öğrenci sayılarının değişsimi. https://istatistik.yok.gov.tr/ sayfasından erişilmiştir.

Yükseköğretim Kurulu [YÖK]. (2013). Yükseköğretim kurumlarında uzaktan öğretime ilişkin usul ve esaslar. https://www.yok.gov.tr/documents/ 10279/34559/ uzaktan_ogretim _esas_usul.pdf/_sayfasından erişilmiştir.

Yükseköğretim Kanunu (1981). Yükseköğretimin amacı. www.mevzuat.gov.tr/Mevzuat Metin/1.5.2547.doc adresinden erişilmiştir.

\section{Introduction}

\section{Extended Abstract}

Some universities in our country have started to carry out all or some of the courses in the associate, undergraduate and graduate curricula and all of the common compulsory courses with distance education. The reason for this orientation of universities to distance education is to be able to respond to increasing student needs, to offer them a qualified education and to support the individual development required by the age. The aim of this study is to evaluate the distance education practice of Turkish language course, which is one of the common compulsory courses in the university curricula, based on the students' opinions. Within this general aim; It is also aimed i) to determine the students' opinions about distance and face-to-face education practices and (ii) to find out the advantages and disadvantages of these education practices when comparing the student opinions on the face-to-face and distance education practices of the Turkish language course. In terms of more effective practices of common compulsory courses; that study is important because it provides data to the people who carry out curriculum development studies, practitioners and possible researches to be done in the fields of distance or face to face education in general, and content, teaching-learning practices and evaluation in particular.

\section{Method}

The study is descriptive and qualitative. The study was designed as a case study. The sample of this study consists of 100 students half of whom are first grade students at the Faculty of Science, Engineering, Medicine, Education and Law at Gazi University in 2016-2017 academic year and the other half of whom are the students who graduated from the same faculties one year ago. The data collection method was interview, and the data was collected using semi-structured interview forms. Content analysis technique was used in the analysis of the data.

\section{Result and Discussion}

According to the findings obtained within the scope of the sub-aims of the study, the students stated that they had problems in each of the content, teaching-learning process and measurementevaluation dimensions of distance learning practice of common compulsory courses.

Content Dimension of the Course: 
The reasons for the negative opinions of the students in both groups are common and these views are related to the difficulty level of the Turkish language course content. The students state that the content of the Turkish language consists of simple topics they learned in their pre-university education experience and it contains unnecessary details. In addition, students think that the lessons are inefficient. The suggestion of the students for solving the problems in the content of the course is to reorganize the subjects in accordance with the university level.

\section{Teaching-Learning Dimension of the Course:}

While students' opinions about distance education practice were concentrated on negative views, they showed a more balanced distribution in terms of face-to-face education practice. The reason for this situation is that while there is only one lecturer telling the lesson in distance education videos, the lecturers who tell the lesson in face-to-face education differ. The students think that the lecturers do not care about the lesson and therefore they use teaching methods and techniques that are based on memorization and not suitable for the course content. The suggestion of the students about teaching-learning dimension is that student-centered teaching methods and techniques be used.

\section{Measurement and Evaluation Dimension of the Course:}

The common reason for both positive and negative views in both groups is that exams are easy. This situation causes exams not to be determinative for students' success levels and lessons and exams are perceived as formality. In addition, the students think that the exams are insufficient and that their levels of success cannot be measured only with tests or written exams. The suggestion of the students for the measurement and evaluation dimension of the course is to make a process evaluation.

\section{Advantages of Distance Education:}

The vast majority of students think that distance education is more advantageous than face to face education. The students listed the reasons for finding distance education advantageous as the absence of absenteeism problems in the lessons, the fact that they can spend more time with them and watch the course videos as much as they want whenever they want.

\section{Disadvantages of Distance Education:}

The disadvantage that students have stated more often about distance education is that they cannot ask questions to the instructors about the problems they have. This situation causes students to find face to face education more efficient. In addition, since students do not have to attend distance education classes, they do not feel obliged to follow the courses and as a result they cannot benefit from distance education.

\section{Advantages of Face to Face Education:}

Students express the most opinions under the "advantages of face to face education" theme. They believe that lessons in face to face practice are handled with the mutual interaction of those who listen and explain the lessons. The students think that the lessons taught by mutual interaction are more permanent and efficient, and therefore they state that face to face education is advantageous.

Considering the Turkish language course as only one of the $5 i$ common compulsory courses at the universities may affect the quality of education in universities in general. In order to eliminate students' negative perceptions, an equal quality / qualified education should be provided for all of the three set of courses in the university curriculum, namely major, elective and common compulsory courses. In order to increase the quality / quality of education, curriculum evaluation study can be done about the Turkish language course. It should be one of the most important task of universities to enable students learn Turkish language perfectly and to train students with national 
Üniversitelerdeki Zorunlu Ortak Derslerden Türk Dili Dersinin Uzaktan ve Yüz Yüze Eğitim Uygulamalarının Karşılaştırılarak Değerlendirilmesi

consciousness. As Atatürk said, the link between the national feeling and the language is very strong. The Turkish language is the heart and mind of the Turkish nation. 